WIESŁAW PARTYKA* - LUBLIN

\title{
BRACTWA RELIGIJNE W DIECEZJI LUBELSKIEJ W XIX WIEKU. STAN LICZBOWY
}

Bractwa religijne pojawiły się już w okresie wczesnośredniowiecznym jako jedna $\mathrm{z}$ form wzmacniania pobożności ${ }^{1}$. Zakładano je zazwyczaj przy klasztorach i kościołach a opiekę duchowną nad ich członkami sprawował kapłan. W Polsce bractwa religijne pojawiły się w XIII wieku - początkowo na Śląsku, a z czasem i na pozostałych terenach ${ }^{2}$. Na Lubelszczyźnie pierwsze bractwa pojawiają się pod koniec XIV stulecia ${ }^{3}$. W okresie przedrozbiorowym na ziemiach polskich funkcjonowało około 80 typów bractw, w większości dewocyjnych, z których największą grupę stanowiły bractwa maryjne (przede wszystkim różańcowe) ${ }^{4}$. Na Lubelszczyźnie, a dokładniej w archidiakonacie lubelskim, wchodzącym w skład diecezji krakowskiej, w okresie przedrozbiorowym funkcjonowały 174 bractwa. Największą grupę stanowiły bractwa związane z kultem maryjnym ${ }^{5}$. Koniec wieku XVIII przyniósł bardzo wiele zmian. Trudna sytuacja gospodarcza i polityczna kraju stała się jedną z przyczyn słabnięcia ruchu brackiego, a wręcz upadku wielu bractw. Wiele bractw zostało zniesionych na skutek kasaty zakonu jezuitów, natomiast na terenach wcielonych do zaboru austriackiego, na skutek reform józefińskich w 1783 roku, nakazano rozwiązanie bractw i przekazanie ich majątków na jedno stowarzyszenie - Bractwo Czynnej Miłości Bliźniego ${ }^{6}$. W podobnym duchu

* Wiesław Partyka - dr pedagogiki, adiunkt w Katedrze Historii Wychowania i Opieki Społecznej, Wydział Nauk Społecznych KUL, e-mail: jezowe@kul.lublin.pl

${ }^{1}$ K. Kuźmiak, Bractwa kościelne, w: Encyklopedia katolicka, Lublin 1985, t. 2, kol. 1013.

${ }^{2}$ Więcej na temat bractw m.in. w: B. Kumor, Kościelne stowarzyszenia świeckich na ziemiach polskich w okresie przedrozbiorowym, „Prawo Kanoniczne”, 10 (1967) nr 1-2, s. 289-356; S. Litak, Bractwa religijne w Polsce przedrozbiorowej. Rozwój i problematyka, „Przegląd Historyczny”, 88 (1997) z. 3-4, s. 499-523; J. Flaga, Bractwa religijne w Rzeczypospolitej w XVII i XVIII wieku, Lublin 2004.

${ }^{3}$ J. Flaga, Bractwa religijne $w$ archidiakonacie lubelskim do końca XVIII wieku, „Archiwa, Biblioteki i Muzea Kościelne" (dalej: ABMK), 42 (1981) s. 295, 316-317.

${ }^{4}$ Litak, Bractwa, s. 518-519; J. Flaga, Bractwa religijne w archidiakonacie lubelskim, s. 329.

${ }^{5}$ Flaga, Bractwa religijne $w$ archidiakonacie lubelskim, s. 328-330.

${ }^{6}$ Kuźmiak, Bractwa, kol. 1015. 
miała przebiegać reforma prymasa M. J. Poniatowskiego, który propagując ideę Bractw Miłosierdzia dążył do inkorporacji dotychczasowych bractw dewocyjnych i ich funduszy do jednego bractwa, które miałoby zajmować się działalnością charytatywną i oświatową. Chodziło tutaj przede wszystkim o przejęcie majątku tych bractw, ponieważ one same nie ulegały rozwiązaniu i nadal mogły zachować swój charakter i nabożeństwo 7 . Kolejne rozbiory, całkowita utrata niepodległości i represyjne działania władz zaborczych wobec Kościoła i wszelkiego rodzaju stowarzyszeń o charakterze społecznym doprowadziły do dalszego upadku dotychczasowych bractw religijnych.

Przełom XVIII/XIX wieku obok wielu zmian politycznych był dla Lubelszczyzny również okresem zmian w organizacji Kościoła. 23 IX 1805 roku papież Pius VII bullą Quemadmodum Romanorum Pontificum utworzył w ramach metropolii lwowskiej diecezję lubelską, w skład której weszły tereny należące wcześniej do diecezji chełmskiej ( 7 dekanatów), łuckiej (4 dekanaty), płockiej (3 dekanaty) i poznańskiej ( 3 dekanaty) ${ }^{8}$. W ciągu kilkunastu kolejnych lat granice nowej diecezji na skutek wojen i przesunięć granic ulegały zmianom, aż do czasu utworzenia w 1815 roku Królestwa Polskiego. Wówczas to diecezję lubelską postanowiono ograniczyć do województwa o tej samej nazwie, co zostało zaaprobowane przez Stolicę Apostolską w 1818 roku'. Diecezja lubelska w takich granicach przetrwała do 1867 roku, kiedy to ukazem cara Aleksandra II skasowana została diecezja janowska (podlaska) a jej terytorium w całości zostało włączone do diecezji lubelskiej i w takiej formie funkcjonowała do I wojny światowej ${ }^{10}$. Po upadku powstania listopadowego ukazem carskim z 7 marca 1837 roku województwa zostały przemianowane na gubernie, a w 1842 roku dotychczasowe obwody na powiaty ${ }^{11}$. W 1844 roku gubernia lubelska znacząco powiększyła swoje terytorium (do $30167 \mathrm{~km}^{2}$ ) na skutek przyłączenia do niej guberni podlaskiej - powstała wówczas druga co do wielkości, po warszawskiej, gubernia w Królestwie Polskim $^{12}$. W 1866 roku gubernia lubelska ponownie została podzielona na dwie - lubelską i siedlecką, co było praktycznie powrotem do granic z 1844 roku $^{13}$. Powyższe rozważania jedynie w zarysie pokazują jak skomplikowanym i ciągle zmieniającym się był proces kształtowania się granic zarówno administracji świeckiej, jak i kościelnej. Jako że władze państwowe dążyły do ujednolicenia granic diecezji i dekanatów z granicami administracji cywilnej można uznać, że granice guberni (wcześniej województwa) i powiatów (wcześniejszych obwodów) pokrywały się z granicami diecezji lubelskiej i dekanatów wchodzących w jej skład.

${ }^{7}$ S. Litak, Od reformacji do Oświecenia. Kościót katolicki w Polsce nowożytnej, Lublin 1994, s. 205.

${ }^{8}$ Dzieje Archidiecezji Lubelskiej (1805-2005), red. M.T. Zahajkiewicz, Lublin 2005, s. 37-38.

${ }^{9}$ Tamże, s. 40.

${ }^{10}$ B. Kumor, Granice metropolii i diecezji polskich (968-1939), ABMK, 20 (1970) s. 316-317, 331.

${ }^{11}$ W. Ćwik, J. Reder, Lubelszczyzna. Dzieje rozwoju terytorialnego, podziałów administracyjnych i ustroju władz, Lublin 1977, s. 93.

12 Tamże.

${ }^{13}$ Tamże, s. 103. 
W latach 1818-1867, kiedy to granice diecezji lubelskiej były najbardziej stabilne w XIX wieku, w skład diecezji wchodziło 12 dekanatów (137 parafii) z liczbą wiernych wynoszącą prawie 380000 i około 200 kapłanami. Po przyłączeniu diecezji janowskiej diecezja lubelska powiększyła się o kolejnych 10 dekanatów (razem było ich 22), jednak na skutek reorganizacji sieci dekanalnej w 1867 roku liczba dekanatów została zredukowana do 19 (236 parafii). Liczba wiernych wynosiła około 810000 i obsługiwana była przez około 400 kapłanów ${ }^{14}$.

Jak to już zostało wcześniej przedstawione bractwa religijne przeżywały duży kryzys począwszy od schyłku XVIII wieku, pogłębiający się w kolejnych latach. Mimo tego, że wizytatorzy wizytujący parafie na przełomie XVIII/XIX wieku zachęcali do kontynuowania ruchu brackiego i reaktywowania bractw tam, gdzie przestały one funkcjonować, to ich działalność ulegała ciągłemu ograniczaniu. Często działo się tak na skutek polityki władz zaborczych. Formalna likwidacja bractw często następowała wraz z kasatą zakonów czy likwidacją klasztorów, przy których one funkcjonowały. Wprawdzie nie oznaczało to definitywnego ustania ich działalności, bo wierni nadal bardzo często gromadzili się na wspólnej modlitwie i dbali o swoje dotychczasowe ołtarze w świątyniach, jednak formalnie przestawały one istniećl ${ }^{15}$. Jeżeli do tego ucisku zaborców doda się charakterystyczny dla I poł. XIX wieku zastój moralny i religijny polskiego społeczeństwa, dotykający wszystkie warstwy społeczne, w tym również duchowieństwo, kasatę zakonów i sekularyzację dóbr kościelnych, to w efekcie doprowadziło to do zahamowania działalności praktycznie we wszystkich dziedzinach życia społecznego i religijnego, w tym również w działalności bractw religijnych.

Głównym zadaniem jakie stawia przed sobą autor, jest przede wszystkim ustalenie stanu liczbowego bractw religijnych na terenie diecezji lubelskiej w XIX wieku. Zatem liczba członków bractw, ich zadania czy zaplecze finansowe na tym etapie nie będą przedmiotem zainteresowania. Jest to zatem pewna próba podjęcia badań nad ruchem brackim w tym okresie, bardzo potrzebna ze względu na brak $\mathrm{w}$ dotychczasowej literaturze naukowej kompleksowego opracowania tego zagadnienia. Należy mieć nadzieję, że doczeka się ono wkrótce bardziej szczegółowych opracowań, jak w przypadku bractw funkcjonujących w Polsce przedrozbiorowej, po to aby lepiej poznać nie tylko funkcjonowanie bractw w całkiem nowej sytuacji politycznej Kościoła polskiego, ale również ich wpływ na odnowę moralną, religijną i być może wzrost nastrojów patriotycznych szerszych grup społecznych.

Ustalenie faktycznej liczby bractw religijnych na terenie diecezji lubelskiej w XIX wieku jest zadaniem dosyć trudnym. Problemem są między innymi dosyć często zmieniające się granice diecezji i przechodzenie parafii czy też całych dekanatów w struktury ościennych biskupstw. Kolejną trudnością są niedokładne dane pochodzące od zarządców parafii dotyczące funkcjonujących tam bractw. Czasami dane te są niekompletne, a czasami wręcz ze sobą sprzeczne. W celu ustalenia liczby i rodzajów bractw religijnych na omawianym terenie wykorzysta-

${ }^{14}$ Dzieje Archidiecezji, s. 45-46; J. Kumor-Mielnik, Sieć dekanalna i parafialna (archi)diecezji lubelskiej w latach 1805-2005, Lublin 2011, s. 37-38.

${ }^{15}$ Flaga, Bractwa religijne w archidiakonacie lubelskim, s. 339-340. 
no dwa podstawowe w tej materii źródła. Pierwszym były akta wizytacji kanonicznych odbywanych przez biskupów lub z ich polecenia w latach 1800-1830 ${ }^{16}$. Po upadku powstania listopadowego aż do końca wieku XIX wizyty biskupie nie miały już miejsca. Wizytacje przekazują informacje na temat wielu bractw, które w późniejszym okresie już nie występowały. Świadczyło to o upadku i zanikaniu tych bractw na skutek różnych przyczyn, o czym była mowa wyżej. Mimo wszystko, nawet jeżeli te bractwa wchodziły w XIX wiek już w schyłkowej fazie swej działalności, to należy je również uwzględnić. Drugim źródłem były dwa spisy bractw sporządzone przez duchowieństwo na polecenie władz rosyjskich. Już w 1824 roku Komisja Rządowa Wyznań Religijnych i Oświecenia Publicznego wystosowała pismo do biskupów z terenu Królestwa Polskiego nakazujące sporządzenie spisu wszystkich bractw. Władza sugerowała, że w bractwach panuje duży

${ }^{16}$ Archiwum Archidiecezjalne Lubelskie (dalej: AAL), Rep 60 A 182, Actus visitationis gen. decanatus Lublinensis 1800; AAL, Rep 60 A 183, Acta Visitationis Generalis Ecclesiarum Prlium Decanatus Casimieriensis per Perillustrum Rnum Vincentium a Gołąbki Jezierski U. J. Dm Canonicum Cathedralem Helmensem Praepositum Collegiatae, Vicarium in Spiritualibus et Officialem Generalem Lublinensem ab Illustrissimo Excellentissimo et Reverendissimo Dno Adalberto Leszczyc de Skarszewski Dei et Apostolicae Sedis Gratia Episcopo Helmensi et Lublinensi, Abbate Commendatario Sulejoviensi, Ordinum Aquitae Albae et Sancti Stanislai Equite Delegatum. Visitationem Generalem Diebus Mensis Octobris Anno 1800 Peractae; AAL, Rep 60 A 184, Actus Visitationis Generalis Decanatus Parczoviensis ab Illustrissimo Excellentissimo ac Reverendissimo Domino Adalberto Leszczyc de Skarszewski Episcopo Helmensi et Lublinensi Peractae Anno Domini 1800; AAL, Rep 60 A 185, Actus Visitationis Generalis Decanatus Chodeliensis ab Illustrissimo Excellentissimo ac Reverendissimo Domino Adalberto Leszczyc de Skarszewski Episcopo Helmensi et Lublinensi Peractae Anno Domini 1801; AAL, Rep 60 A 186, Actus Visitationis Generalis Decanatus Urzendoviensis ab Illustrissimo Excellentissimo ac Reverendissimo Domino Adalberto Leszczyc de Skarszewski Episcopo Helmensi et Lublinensi Peractae Anno Domini 1801; AAL, Rep 60 A 188, Visitatio Ecclesiarum Decanatus Lublinensis. Peracta 1799-1804 Annis; AAL, Rep 60 A 189, Visitatio Ecclesiarum Decanatus Chodeliensis. Peracta 1801, 1805, 1806 anno; AAL, Rep 60 A 190, Visitatio Ecclesiarum Decanatus Kuroviensis. Anno 1803 peracta; AAL, Rep 60 A 191, Visitatio Ecclesiarum Decanatus Krasnostaviensis. Peracta 1803 anno; AAL, Rep 60 A 192, Visitatio Ecclesiarum Decanatus Chełmensis. Peracta Anno Domini 1804; AAL, Rep 60 A 193, Visitatio Ecclesiarum Decanatus Parczoviensis. Peracta 1805 anno; AAL, Rep 60 A 195, Visitatio Ecclesiarum Decanatus Zaklikoviensis. Peracta Anno Domini 1806; AAL, Rep 60 A 196a, Visitatio Ecclesiarum Decanatus Łukoviensis. Peracta 1807-1808 anno; AAL, Rep 60 A 197, Visitatio Ecclesiarum Decanatus Stężycensis. Peracta 1808 anno; AAL, Rep 60 A 198, Visitatio Ecclesiarum Decanatus Węgroviensis. Anno 1808 peracta; AAL, Rep 60 A 199, Visitatio Ecclesiarum Decanatus Zaklikoviensis Dioecesis Kielcensis post annum 1814 per Decanum peractae; AAL, Rep 60 A 202, Visitatio Ecclesiarum Decanatus Hrubieszoviensis. Peracta 1816-1817 anno; AAL, Rep 60 A 203, Visitatio Ecclesiarum Decanatus Zamoscensis. Peracta 1817 anno; AAL, Rep 60 A 204, Visitatio Ecclesiarum Decanatus Tarnogrodensis. Peracta Anno Domini 1817; AAL, Rep 60 A 205, Visitatio Ecclesiarum Dioecesis Lublinensis tempore Episcopatus Illmi Josephi Marcellini Dzięcielski (anno 1830) peractae. Vol. I; AAL, Rep 60 A 206, Visitatio Ecclesiarum Dioecesis Lublinensis tempore Episcopatus Illmi Josephi Marcellini Dzięcielski (anno 1830) peractae. Vol. II; AAL, Rep 60 A 207, Visitatio Ecclesiarum Dioecesis Lublinensis tempore Episcopatus Illmi Josephi Marcellini Dzięcielski (anno 1830) peractae. Vol. III; AAL, Rep 60 A 208, Visitatio Ecclesiarum Dioecesis Lublinensis tempore Episcopatus Illmi Josephi Marcellini Dzięcielski (anno 1830) peractae. Vol. IV. 
nieporządek i brakuje kontroli nad dochodami brackimi ${ }^{17}$. Pierwszy spis pochodzi z lat 1833-1834. W 1833 roku Komisja Rządowa Spraw Wewnętrznych Duchownych i Oświecenia Publicznego w piśmie do biskupa lubelskiego poinformowała, że chce otrzymać informacje dotyczące bractw istniejących przy kościołach i klasztorach na terenie diecezji. Biskup został zobowiązany do poinformowania plebanów i przełożonych klasztorów, aby ci przygotowali wszelkie dane zgodne z załączonym do pisma schematem. W odpowiedzi na to pismo biskup Dzięcielski 1 III 1833 roku skierował pismo do Konsystorza Generalnego Lubelskiego, aby ten poinformował o tym przedsięwzięciu wszystkich zarządców kościołów i klasztorów i aby ci nadesłali stosowne informacje biskupowi ${ }^{18}$. Pierwszy wykaz bractw został przedstawiony już 8 maja 1833 roku, jednak na skutek reskryptu Komisji Rządowej z 2 stycznia 1834 roku, aby uzupełnić szereg danych, szczególnie odnoszących się do dokumentów erekcyjnych i funduszy jakimi bractwa dysponowały, 24 maja 1834 roku przygotowany został poprawiony i uzupełniony o te informacje wykaz bractw na terenie diecezji lubelskiej ${ }^{19}$. Kolejny spis bractw w diecezji lubelskiej przeprowadzony został w latach 1888-1889. Generał-gubernator warszawski pismem z 26 marca 1888 roku zażądał, aby w ciągu siedmiu miesięcy przygotować szczegółowy wykaz bractw przy kościołach w diecezji. Wykaz ten miał być narzędziem decydującym o tym, które bractwa mogą zostać uznane przez rząd za prawnie funkcjonujące i czy rząd może zaakceptować ustawy tych stowarzyszeń religijnych. 30 IV 1888 roku wystosowane zostało przez administratora diecezji lubelskiej (wówczas na stolicy biskupiej był vacat) pismo do dziekanów z prośbą o przygotowanie takich wykazów dla swoich dekanatów ${ }^{20}$. Należy pamiętać, że w tym okresie diecezja lubelska była powiększona o tereny dołączone w wyniku likwidacji diecezji podlaskiej. Wykaz bractw został przygotowany i przedstawiony władzom w 1889 roku. Wykaz bractw z 1833 roku jest bardziej szczegółowy od tego późniejszego. Przekazuje takie informacje jak: nazwa bractwa, kto kieruje bractwem, data ustanowienia, liczba członków, cel bractwa, fundusze. Wykaz z 1889 roku skupia się jedynie na nazwie bractwa, roku założenia i zatwierdzenia oraz dokumentach, które ten fakt mogą potwierdzić. Oczywiście zarówno w pierwszym jak i w drugim wykazie dane dotyczące bractw nie są kompletne. Dużym problemem, nawet mimo starań duchowieństwa parafialnego, było ustalenie daty erekcji poszczególnych bractw, co najczęściej wiązało się z zaginięciem dokumentów fundacyjnych na skutek klęsk elementarnych, wojen czy zwykłych zaniedbań. Często można spotkać zarówno w wizytacjach, jak i w wykazach nieścisłości co do daty wprowadzenia bractwa w parafii. W przypadku jednego bractwa można natknąc się nawet na kilka różnych od siebie dat. Było to wynikiem podawania albo daty wprowadzenia bractwa w parafii, albo daty zatwierdzenia bractwa w parafii przez władze kościelne lub zakonne, czasami można się spotkać z datą odpustu nadanego bractwu przez papieża czy też mogła to być data reaktywowania bractwa w parafii. Brak dokumentów erekcyj-

\footnotetext{
${ }^{17}$ Dzieje Archidiecezji, s. 209-210.

${ }^{18}$ AAL, Rep 60 IX 1, O bractwach istniejących przy kościołach 1833-1876, s. 1-5.

${ }^{19}$ Tamże, s. 290-319.

${ }^{20}$ AAL, Rep 60 IX 3, O Bractwach istniejących przy kościołach 1888-1890, s. 3.
} 
nych stwarzał często formalny pretekst dla władzy państwowej, aby ograniczać lub też całkowicie zakazywać działalności takich bractw. Z tego też powodu wielu kapłanów sprawujących opiekę nad bractwami występowało w pismach do biskupa z prośbą o ponowne erygowanie bractwa, aby mogły one nadal legalnie funkcjonować. W przypadku części bractw nie udało się ustalić na podstawie źródeł żadnej z powyższych dat, a zarządcy parafii albo w ogóle milczeli na ten temat, albo swoją niewiedzę tłumaczyli zaginięciem dokumentów, dawnością bractwa, itp. Nie zawsze też administratorzy parafii przekazywali informacje na temat bractw, co mogło wynikać z ich opieszałości, niedbalstwa czy innych powodów. Jeżeli informacja przesłana do Konsystorza dotarła zbyt późno nie była uwzględniana w przygotowanym wykazie. Podobnie rzecz mogła wyglądać z niestarannie przygotowanymi, niekompletnymi czy zbyt lakonicznymi informacjami, które mogły być niezamieszczane. Niezbędną pomocą służącą m.in. uporządkowaniu dat erekcji poszczególnych bractw była praca Jerzego Flagi dotycząca bractw $\mathrm{w}$ archidiakonacie lubelskim $\mathrm{w}$ okresie przedrozbiorowym ${ }^{21}$. Opierając się na aktach wizytacyjnych i innych źródłach proweniencji kościelnej ustalił on wiele danych, które w przypadku braku informacji w źródłach XIX-wiecznych zostały wykorzystane w celu przedstawienia w miarę kompletnego obrazu.

Według spisu, przeprowadzonego w 1833 r. na terenie diecezji lubelskiej istniało 70 bractw religijnych przy 63 kościołach. Większość z nich stanowiły bractwa różańcowe, których było aż 43. Sprawozdanie to przekazało również, że łącznie w szeregach tych bractw funkcjonowało 5373 osób. Wykaz bractw z 1889 roku przedstawiał 106 konfraterni w diecezji lubelskiej i 84 na terenie dawnej diecezji podlaskiej, czyli razem 190 bractw $^{22}$. Mimo iż w porównaniu ze spisem z 1833 roku liczba bractw w diecezji lubelskiej teoretycznie uległa zwiększeniu, to może dziwić dołączona do spisu notatka mówiąca o zaniku działalności 16 bractw $\mathrm{w}$ porównaniu $\mathrm{z}$ okresem wcześniejszym ${ }^{23}$. Według wykazu w okresie pomiędzy tymi dwoma spisami powstało zaledwie kilka nowych bractw. Skąd zatem takie rozbieżności w danych? Należy przypuszczać że kilkadziesiąt bractw z pierwszej połowy XIX wieku po prostu nie zostało uwzględnionych w spisie z 1833 roku. Przyczyną takiego stanu rzeczy mogło być albo zbyt późne nadesłanie sprawozdań z niektórych parafii albo z różnych przyczyn nienadesłanie takich informacji wcale. Należy zatem przyjąć, że w I połowie XIX wieku na terenie diecezji lubelskiej liczba bractw religijnych była większa niż wynikało to z oficjalnego spisu. Za tą tezą przemawia również fakt, że część bractw uwzględnionych w wykazie z 1889 roku, a których brak w wykazie z 1833 roku istniała na początku XIX wieku, o czym świadczą informacje na ich temat w aktach wizytacji kanonicznych z tego okresu. Jeżeli zatem podda się analizie zarówno wizytacje jak i oficjalne wykazy, to ogólna liczba bractw religijnych na terenie diecezji lubelskiej w XIX wieku wynosiła 199. Nie uwzględnia się tu bractw znajdujących się w parafiach dołączonych do diecezji lubelskiej po likwidacji diecezji podlaskiej, z wyjątkiem tych, które istniały przy parafiach wchodzących na początku XIX wieku w skład diece-

\footnotetext{
${ }^{21}$ Flaga, Bractwa religijne $w$ archidiakonacie lubelskim.

${ }^{22}$ Tamże, s. 536-540.

${ }^{23}$ Tamże, s. 540.
} 
zji lubelskiej, a później na skutek zmiany granic od niej odpadły. Zdecydowana większość tych bractw zaprowadzona została w XVII i XVIII wieku, bardzo nieliczne pochodzą z okresu wcześniejszego, a z XIX stulecia tylko kilkanaście. Zdecydowaną większość stanowiły bractwa maryjne - było ich aż 124 z czego 91 różańcowych, 24 szkaplerznych i 9 innych. Spośród innych bractw dosyć licznie reprezentowanych należy wymienić bractwa noszące wezwanie Św. Trójcy (24), św. Anny (15), Miłosierdzia (12). Zdecydowanie mniej było takich bractw jak: Bożego Ciała (3), św. Tekli (3), św. Jana Nepomucena (3), Literackie (2), św. Antoniego (2), Serca Jezusowego (2). Po jednym odnotowano takie bractwa jak: Aniołów Stróżów, Imienia Jezus, Miłośników Jezusa Ukrzyżowanego, Jezusa Miłosiernego (Konających), św. Krzyża, św. Marii Magdaleny, św. Barbary, św. Iwona, Paska św. Franciszka z Asyżu. Większość parafii w opisywanym okresie posiadało tylko 1 bractwo (100), 2 bractwa odnotowano przy 36 kościołach, 3 przy 7 kościołach, 4 bractwa w XIX wieku odnotowano w parafii Józefów, aż 6 bractw funkcjonowało w Lublinie przy kościele Bernardynów. Niektóre bractwa funkcjonowały nieprzerwanie przez cały omawiany okres, inne zanikały lub pojawiały się tylko na pewien czas. Wraz z początkiem XIX wieku całkowicie zanikły m.in. bractwa Miłosierdzia zakładane pod koniec XVIII stulecia za sprawą prymasa Poniatowskiego. Przyczyną ich zaniku był przede wszystkim brak funduszy, co sprawiało, że bractwa te nie miały żadnych podstaw do prowadzenia swojej działalności. W poniższym wykazie uwzględniono również te parafie i bractwa, które tylko przez krótki okres znajdowały się w granicach diecezji lubelskiej, aby później znaleźć się w diecezji podlaskiej ( 23 parafie -31 bractw). W poniższej tabeli nie uwzględniano przynależności poszczególnych parafii do dekanatów ze względu na częste zmiany sieci dekanalnej zachodzące w XIX wieku o czym była mowa wyżej. 
Tab. 1. Bractwa religijne w diecezji lubelskiej w XIX wieku/

Table 1. Religious brotherhoods in the Diocese of Lublin in the 19th century.

\begin{tabular}{|c|c|c|c|c|c|c|}
\hline Lp. & $\begin{array}{c}\text { Parafia/ } \\
\text { parish }\end{array}$ & $\begin{array}{c}\text { Nazwa brac- } \\
\text { twa/ the name } \\
\text { of the brother- } \\
\text { hood }\end{array}$ & $\begin{array}{l}\text { Data wprowa- } \\
\text { dzenia/ the da- } \\
\text { te of the intro- } \\
\text { duction to a } \\
\text { parish }\end{array}$ & $\begin{array}{c}\text { Data aprobaty } \\
\text { (zatwierdzenia)/ } \\
\text { the date of ap- } \\
\text { proval }\end{array}$ & $\begin{array}{l}\text { Lata wzmia- } \\
\text { nek źródlo- } \\
\text { wych/ the } \\
\text { years of so- } \\
\text { urce referen- } \\
\text { ces } \\
\end{array}$ & $\begin{array}{l}\text { Źródla/ } \\
\text { sources }\end{array}$ \\
\hline 1. & Abramowice & Św. Trójcy & $(1800-1804)^{24}$ & & 1804 & $\begin{array}{l}\text { AAL, Rep } 60 \\
\text { A } 188, \text { s. } 54 \mathrm{v}\end{array}$ \\
\hline 2. & Annopol & $\begin{array}{c}\text { Niepokalane- } \\
\text { go Poczęcia } \\
\text { NMP }\end{array}$ & 1745 & $1751-1752^{25}$ & $\begin{array}{l}1806,1814, \\
1833,1889\end{array}$ & $\begin{array}{c}\text { AAL, Rep } 60 \\
\text { A 195, s. } 301 ; \\
\text { AAL, Rep } 60 \\
\text { A } 199, \text { s. } 15 ; \\
\text { AAL, Rep } 60 \\
\text { IX 1, s. 213, } \\
\text { 291; AAL, } \\
\text { Rep } 60 \text { IX 3, } \\
\text { s. } 537 \mathrm{v}\end{array}$ \\
\hline 3. & Baranów & Różańcowe & $1670^{26}$ & 1678 & $\begin{array}{c}1800,1803, \\
1830,1889\end{array}$ & $\begin{array}{c}\text { AAL, Rep } 60 \\
\text { A 183, s. } \\
\text { 212v; AAL, } \\
\text { Rep } 60 \text { A 190, } \\
\text { s. } 365 ; \text { AAL, } \\
\text { Rep } 60 \text { A 205, } \\
\text { s. } 118 \mathrm{v} \text {; AAL, } \\
\text { Rep } 60 \text { IX } 3 \text {, } \\
\text { s. } 536 \mathrm{v}\end{array}$ \\
\hline 4. & Batorz & $\begin{array}{l}\text { Świętych } \\
\text { Aniołów } \\
\text { Stróżów }\end{array}$ & 29 XI $1699^{27}$ & 1801 & $\begin{array}{c}1801,1833 \\
1889\end{array}$ & $\begin{array}{c}\text { AAL, Rep } 60 \\
\text { A } 186, \text { s. } 84 ; \\
\text { AAL, Rep } 60 \\
\text { IX 1, s. 227, } \\
\text { 229, 265-266; } \\
\text { AAL, Rep } 60 \\
\text { IX 3, s. } 537\end{array}$ \\
\hline 5. & Bełżyce & $\begin{array}{l}\text { Różańcowe } \\
\text { Szkaplerzne }\end{array}$ & 1660 & 26 VIII 1672 & $\begin{array}{c}1800,1833, \\
1889 \\
\\
1889\end{array}$ & $\begin{array}{c}\text { AAL, Rep } 60 \\
\text { A 182, s. 299; } \\
\text { AAL, Rep } 60 \\
\text { IX 1, s. 136; } \\
\text { AAL, Rep } 60 \\
\text { X 3, s. } 536 \\
\text { AAL, Rep } 60 \\
\text { IX 3, s. 1, } 536\end{array}$ \\
\hline
\end{tabular}

${ }^{24}$ Według wizytacji z roku 1800 (AAL, Rep 60 A 182, s. 39) w parafii nie było bractwa; według wizytacji z roku 1804 (AAL, Rep 60 A 188, s. 54v) funkcjonowało już bractwo - zob. Flaga, Bractwa $w$ archidiakonacie lubelskim, s. 302-303.

${ }^{25}$ Pozwolone 8 X 1751 w Rzymie przez Benedykta XIV a 6 III 1752 przyjęte przez konsystorz krakowski (AAL, Rep 60 IX 1, s. 265-266).

${ }^{26}$ Flaga, Bractwa religijne $w$ archidiakonacie lubelskim, s. 302-303; Ponowne wprowadzenie i zatwierdzenie bractwa miało miejsce w 1845 roku (AAL, Rep 60 IX 2, s. 5).

${ }^{27}$ Według wykazu bractw z 1889 roku bractwo to zostało założone w 1640 roku (AAL, Rep 60 X 3, s. 537). 


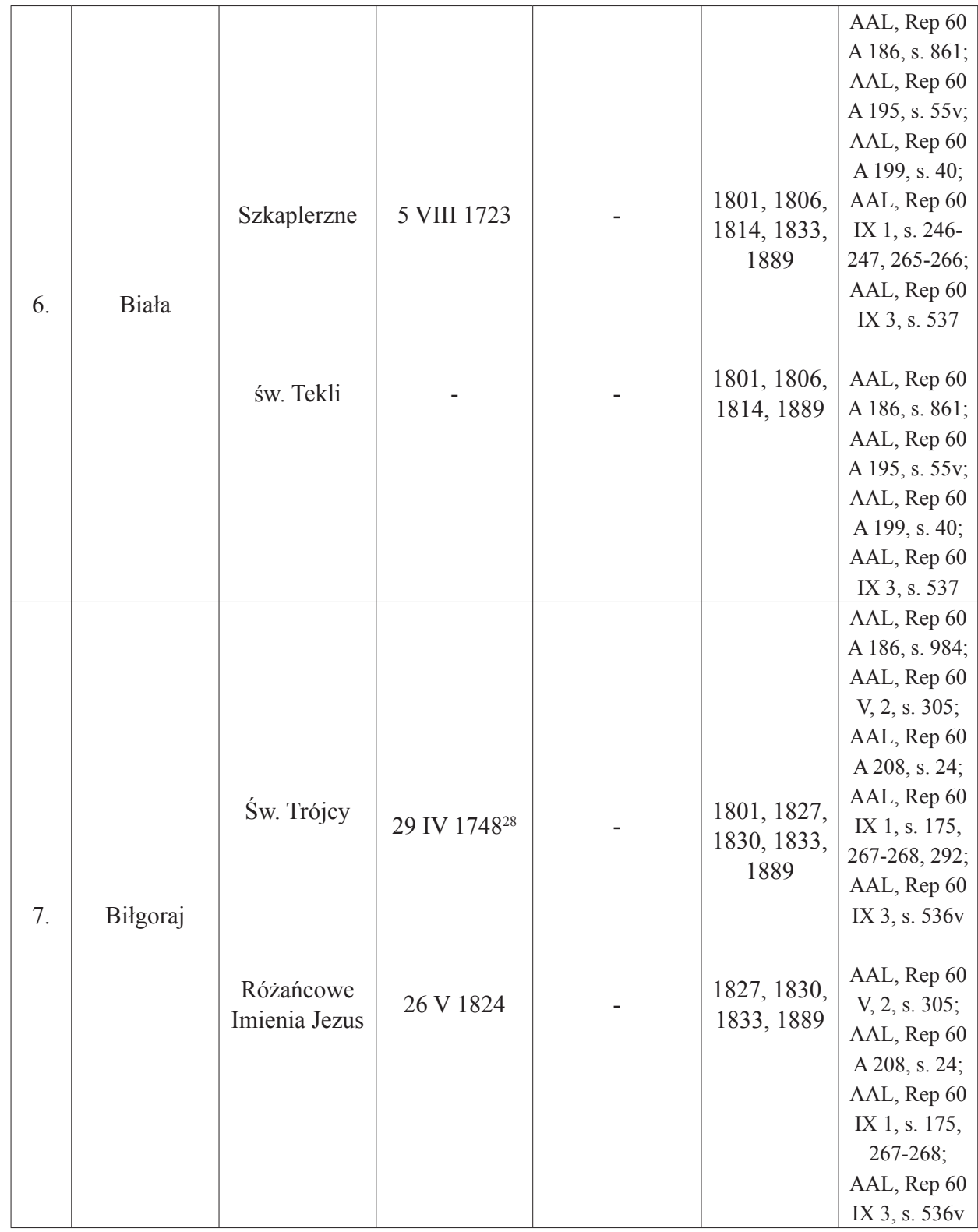

${ }^{28}$ Według wykazu bractw z 1889 roku powstało ono w 1743 roku (AAL, Rep 60 X 3, s. 536v) 


\begin{tabular}{|c|c|c|c|c|c|c|}
\hline 8. & Biskupice & $\begin{array}{l}\text { Różańcowe } \\
\text { Miłosierdzia }\end{array}$ & $\begin{array}{c}1786^{29} \\
\text { koniec XVIII } \\
\text { wieku }^{30}\end{array}$ & - & $\begin{array}{c}1800,1833, \\
1889 \\
\\
1800\end{array}$ & $\begin{array}{c}\text { AAL, Rep } 60 \\
\text { A } 184, \text { s. } 610 ; \\
\text { AAL, Rep } 60 \\
\text { IX 1, s. } 155- \\
156,160-161 \text {, } \\
279-280,291 ; \\
\text { AAL, Rep } 60 \\
\text { IX 3, s. } 536 \\
\text { AAL, Rep } 60 \\
\text { A } 184, \text { s. } 610\end{array}$ \\
\hline 9 & Bobrowniki & $\begin{array}{l}\text { Różańcowe } \\
\text { św. Anny }\end{array}$ & $\begin{array}{l}1595 \\
1595\end{array}$ & - & $\begin{array}{l}1889 \\
1889\end{array}$ & $\begin{array}{c}\text { AAL, Rep } 60 \\
\text { IX 3, s. } 536 \\
\text { AAL, Rep } 60 \\
\text { IX 3, s. } 536 \\
\end{array}$ \\
\hline 10. & Boby & Św. Trójcy & 10 XI $1781^{31}$ & 1781 & 1801,1833 & $\begin{array}{c}\text { AAL, Rep } 60 \\
\text { A } 185, \text { s. } 198 ; \\
\text { AAL, Rep } 60 \\
\text { IX 1, s. 200- } \\
\text { 202, 279-280 }\end{array}$ \\
\hline 11. & Borów & Szkaplerzne & $1737^{32}$ & - & 1801,1814 & $\begin{array}{c}\text { AAL, Rep } 60 \\
\text { A 186, s. 617; } \\
\text { AAL, Rep } 60 \\
\text { A 199, s. 18; } \\
\text { AAL, Rep } 60 \\
\text { IX 3, s. } 537\end{array}$ \\
\hline 12. & Bychawka & Szkaplerzne & 26 VII 1740 & - & 1801,1827 & $\begin{array}{c}\text { AAL, Rep } 60 \\
\text { A } 185, \text { s. } 662 ; \\
\text { AAL, Rep } 60 \\
\text { V, 2, s. } 169\end{array}$ \\
\hline 13. & Bystrzyca & $\begin{array}{l}\text { Św. Trójcy } \\
\text { Miłosierdzia }\end{array}$ & 1773 & 3 IX 1774 & $\begin{array}{c}1800,1805, \\
1889 \\
1800\end{array}$ & $\begin{array}{c}\text { AAL, Rep } 60 \\
\text { A } 184, \text { s. } 412 ; \\
\text { AAL, Rep } 60 \\
\text { A } 193, \text { s. } 96 ; \\
\text { AAL, Rep } 60 \\
\text { IX 3, s. } 536 \\
\text { AAL, Rep } 60 \\
\text { A } 184, \text { s. } 412\end{array}$ \\
\hline
\end{tabular}

${ }^{29}$ Pojawiają się również daty wcześniejszego ustanowienia tego bractwa - 1677 (AAL, Rep 60 IX 3, s. 1); 1639-1643 (Flaga, Bractwa religijne w archidiakonacie lubelskim, s. 302-303).

${ }^{30}$ Mimo braku informacji o dacie powstania tego bractwa, należy przypuszczać, że chodzi o bractwa miłosierdzia propagowane przez prymasa Poniatowskiego, powstające pod koniec XVIII wieku.

${ }^{31}$ Według wykazu bractw z 1889 roku bractwo to wprawdzie już nie funkcjonowało, ale zamieszczona została informacja, że założone zostało w 1700 roku (AAL, Rep 60 X 3, s. 540v).

${ }^{32}$ Według wykazu bractw z 1889 roku bractwo to założone zostało w 1743 roku (AAL, Rep 60 X 3, s. 537). 


\begin{tabular}{|c|c|c|c|c|c|c|}
\hline 14. & Chełm & $\begin{array}{c}\text { Serca } \\
\text { Jezusowego } \\
\text { Matki Bożej } \\
\text { Łaskawej }\end{array}$ & $\begin{array}{c}- \\
1731\end{array}$ & - & $\begin{array}{c}1804 \\
1804,1889\end{array}$ & $\begin{array}{l}\text { AAL, Rep } 60 \\
\text { A 192, s. 50v } \\
\\
\text { AAL, Rep } 60 \\
\text { A 192, s. } 50 \mathrm{v} ; \\
\text { AAL, Rep } 60 \\
\text { IX 3, s. } 537\end{array}$ \\
\hline 15. & Chodel & $\begin{array}{l}\text { Bożego Ciała } \\
\text { Różańcowe }\end{array}$ & $\begin{array}{r}1613 \\
1653\end{array}$ & $\begin{array}{c}1619^{33} \\
-\end{array}$ & $\begin{array}{c}1801,1827, \\
1830,1889 \\
1889\end{array}$ & $\begin{array}{c}\text { AAL, Rep } 60 \\
\text { A } 185, \text { s. } 44 ; \\
\text { AAL, Rep } 60 \\
\text { V, 2, s. } 173 \mathrm{v} ; \\
\text { AAL, Rep 60, } \\
\text { A 205, s. } 362 ; \\
\text { AAL, Rep } 60 \\
\text { IX 3, s. } 536 \\
\text { AAL, Rep } 60 \\
\text { IX 3, s. } 540 \text { v }\end{array}$ \\
\hline 16. & Czemierniki & $\begin{array}{l}\text { Różańcowe } \\
\text { Miłośników } \\
\text { Jezusa Ukrzy- } \\
\text { żowanego }\end{array}$ & 19 IV 1633 & 4 XII 1633 & $\begin{array}{c}1800,1833 \\
1889\end{array}$ & $\begin{array}{c}\text { AAL, Rep } 60 \\
\text { A 184, s. 125; } \\
\text { AAL, Rep } 60 \\
\text { IX 1, s. 155- } \\
\text { 156, 277-278; } \\
\text { AAL, Rep } 60 \\
\text { IX 3, s. 537v } \\
\\
\text { AAL, Rep } 60 \\
\text { A 184, s. } 125 \text {; } \\
\text { AAL, } \\
\text { Rep } 60 \text { IX 1, } \\
\text { s. } 155-156, \\
\text { 158, 277-278, } \\
294\end{array}$ \\
\hline 17. & $\begin{array}{l}\text { Częstoboro- } \\
\text { wice }\end{array}$ & Różańcowe & $1703^{34}$ & - & $\begin{array}{c}1800,1804, \\
1827,1833, \\
1889\end{array}$ & $\begin{array}{c}\text { AAL, Rep } 60 \\
\text { A } 182, \text { s. } 139 ; \\
\text { AAL, Rep } 60 \\
\text { A 188, s. } \\
\text { 108v; AAL, } \\
\text { Rep } 60 \text { V, } 2 \text {, } \\
\text { s. } 128 ; \text { AAL, } \\
\text { Rep } 60 \text { IX 1, } \\
\text { s. 126; AAL, } \\
\text { Rep } 60 \text { IX 3, } \\
\text { s. } 537 \mathrm{~V}\end{array}$ \\
\hline 18. & Dorohusk & Szkaplerzne & - & - & 1804 & $\begin{array}{c}\text { AAL, Rep } 60 \\
\text { A 192, s. } \\
139 \mathrm{v}\end{array}$ \\
\hline
\end{tabular}

${ }^{33}$ J. Flaga podaje, że bractwo to wprowadzone zostało 4 VII 1613 r., a zatwierdzone 10 X 1613 roku (Flaga, Bractwa religijne w archidiakonacie lubelskim, s. 304).

${ }^{34}$ Według wykazu bractw z 1889 roku bractwo to powstało w 1733 roku (AAL, Rep 60 IX 3, s. $537 \mathrm{v})$. 


\begin{tabular}{|c|c|c|c|c|c|c|}
\hline 19. & Drążgów & Św. Trójcy & - & - & 1808 & $\begin{array}{c}\text { AAL, Rep } 60 \\
\text { A 197, s. } \\
426 \mathrm{v}\end{array}$ \\
\hline 20. & Dubienka & $\begin{array}{c}\text { Różańcowe } \\
\text { Szkaplerzne }{ }^{35}\end{array}$ & $\begin{array}{r}1754 \\
1790\end{array}$ & $\begin{array}{c}- \\
1802\end{array}$ & $\begin{array}{c}1804,1833, \\
1889 \\
\\
1804,1834, \\
1889\end{array}$ & $\begin{array}{c}\text { AAL, Rep } 60 \\
\text { A 192, s. 155- } \\
\text { 155v; AAL, } \\
\text { Rep } 60 \text { IX 1, } \\
\text { s. 64-65, 74- } \\
\text { 75, 263-264, } \\
\text { 293, 294; } \\
\text { AAL, Rep } 60 \\
\text { IX 3, s. } 537 \\
\text { AAL, Rep } 60 \\
\text { A 192, s. } 155- \\
\text { 155v; } \\
\text { AAL, Rep } 60 \\
\text { IX 1, s. } 74- \\
75 ; \text { AAL, Rep } \\
\text { 60 IX 3, s. } \\
537\end{array}$ \\
\hline 21. & Dys & Różańcowe & $31 \times 1728$ & - & $\begin{array}{l}1800,1830 \\
1833,1889\end{array}$ & $\begin{array}{c}\text { AAL, Rep } 60 \\
\text { A } 184, \text { s. } 373 ; \\
\text { AAL, Rep } 60 \\
\text { A 205, s. } \\
\text { 395v; AAL, } \\
\text { Rep } 60 \text { IX 1, } \\
\text { s. 155-156, } \\
\text { 160-161, 279- } \\
280,294 ; \\
\text { AAL, Rep } 60 \\
\text { IX 3, s. 537v }\end{array}$ \\
\hline 22. & Dzierążnia & Różańcowe & - & - & 1830 & $\begin{array}{l}\text { AAL, Rep } 60 \\
\text { A 208, s. } 316\end{array}$ \\
\hline 23. & $\begin{array}{l}\text { Dzierzkowi- } \\
\text { ce }\end{array}$ & św. Anny & $30 \mathrm{VI} 1766$ & - & $\begin{array}{c}1801,1814 \\
1833\end{array}$ & $\begin{array}{c}\text { AAL, Rep } 60 \\
\text { A } 186, \text { s. } 388 ; \\
\text { AAL, Rep } 60 \\
\text { A } 199, \text { s. } 62 \text {; } \\
\text { AAL, Rep } 60 \\
\text { IX 1, s. } 205- \\
\text { 206, 207, } \\
263-264\end{array}$ \\
\hline
\end{tabular}

${ }^{35}$ Jeszcze w 1804 roku funkcjonowało jako odrębne bractwo, jednak w 1834 roku pojawia się informacja, że bractwo to zostało połączone w jedno z bractwem różańcowym (AAL, Rep 60 IX 1, s. 74-75). Zgodnie z wykazem z 1889 roku w Dubience funkcjonowały ponownie dwa bractwa (AAL, Rep 60 IX 3, s. 537). 


\begin{tabular}{|c|c|c|c|c|c|c|}
\hline 24. & Fajsławice & $\begin{array}{l}\text { Św. Trójcy } \\
\text { Miłosierdzia }\end{array}$ & $\begin{array}{l}1765 \\
1790\end{array}$ & - & $\begin{array}{l}1800,1804 \\
1800,1804\end{array}$ & $\begin{array}{c}\text { AAL, Rep } 60 \\
\text { A } 182, \text { s. } 334 ; \\
\text { AAL, Rep } 60 \\
\text { A } 188, \text { s. } \\
137 \mathrm{v}-138 \\
\text { AAL, Rep } 60 \\
\text { A } 182, \text { s. } 334 ; \\
\text { AAL, Rep } 60 \\
\text { A } 188, \text { s. } \\
137 \mathrm{v}-138\end{array}$ \\
\hline 25. & Garbów & Różańcowe & 1667 & - & $\begin{array}{c}1800,1803, \\
1827,1833, \\
1889\end{array}$ & $\begin{array}{c}\text { AAL, Rep } 60 \\
\text { A 183, s. } \\
\text { 190v; AAL, } \\
\text { Rep } 60 \text { A 190, } \\
\text { s. 670; AAL, } \\
\text { Rep 60 V, 2, } \\
\text { s. 253v, AAL, } \\
\text { Rep } 60 \text { IX 1, } \\
\text { s. 87, 107- } \\
\text { 108, 261-262, } \\
\text { 293-294; } \\
\text { AAL, Rep 60 } \\
\text { IX 3, s. 536v }\end{array}$ \\
\hline 26. & Goraj & Różańcowe & 7 IX 1530 & - & $\begin{array}{c}1801,1833, \\
1889\end{array}$ & $\begin{array}{c}\text { AAL, Rep } 60 \\
\text { A 186, s. } \\
\text { 1075; AAL, } \\
\text { Rep } 60 \text { IX 1, } \\
\text { s. 228, 232, } \\
267-268,294\end{array}$ \\
\hline 27. & Gorzków & $\begin{array}{l}\text { Różańcowe } \\
\text { Św. Trójcy }\end{array}$ & 9 III $1729^{36}$ & - & $\begin{array}{c}1803,1833, \\
1889 \\
1803\end{array}$ & $\begin{array}{l}\text { AAL, Rep } 60 \\
\text { A } 191, \text { s. } 37 \mathrm{v} ; \\
\text { AAL, Rep } 60 \\
\text { IX 1, s. } 127 \text {, } \\
271-272,296 ; \\
\text { AAL, Rep } 60 \\
\text { IX 3, s. } 537 \mathrm{v} \\
\text { AAL, Rep } 60 \\
\text { A } 191, \text { s. } 37 \mathrm{v}\end{array}$ \\
\hline 28 & Gostyń & $\begin{array}{l}\text { Św. Trójcy } \\
\text { św. Anny }\end{array}$ & $\begin{array}{l}- \\
-\end{array}$ & - & $\begin{array}{l}1808 \\
1808\end{array}$ & $\begin{array}{l}\text { AAL, Rep } 60 \\
\text { A } 198, \text { s. } 153 \\
\text { AAL, Rep } 60 \\
\text { A } 198, \text { s. } 153\end{array}$ \\
\hline
\end{tabular}

${ }^{36}$ Wedhug wykazu bractw z 1889 roku bractwo to zostało wprowadzone w 1728 r. (AAL, Rep 60 IX 3, s. 537v). 


\begin{tabular}{|c|c|c|c|c|c|c|}
\hline 29. & Gościeradów & Różańcowe & 1728 & - & $\begin{array}{c}1801,1814, \\
1889\end{array}$ & $\begin{array}{c}\text { AAL, Rep } 60 \\
\text { A 186, s. 640; } \\
\text { AAL, Rep } 60 \\
\text { A 199, s. 56; } \\
\text { AAL, Rep } 60 \\
\text { IX 3, s. } 537\end{array}$ \\
\hline 30. & Górecko & Szkaplerzne & - & - & $\begin{array}{l}1817,1830 \\
1833,1889\end{array}$ & $\begin{array}{c}\text { AAL, Rep } 60 \\
\text { A 204, s. } 87 ; \\
\text { AAL, Rep } 60 \\
\text { A 208, s. } 210 ; \\
\text { AAL, Rep } 60 \\
\text { IX 1, s. 176, } \\
\text { 177, 267-268, } \\
\text { 296; AAL, } \\
\text { Rep } 60 \text { IX } 3 \text {, } \\
\text { s. } 536 \text { v }\end{array}$ \\
\hline 31. & Górzno & Różańcowe & 1713 & - & 1808,1889 & $\begin{array}{c}\text { AAL, Rep } 60 \\
\text { A 197, s. } \\
117 \mathrm{v} ; \text { AAL, } \\
\text { Rep } 60 \text { IX } 3, \\
\text { s. } 538 \mathrm{v}\end{array}$ \\
\hline 32. & Grabowiec & Różańcowe & - & - & 1833 & $\begin{array}{c}\text { AAL, Rep } 60 \\
\text { IX 1, s. 64- } \\
65,263-264 \text {, } \\
295\end{array}$ \\
\hline 33. & Horodło & Różańcowe & - & - & $\begin{array}{c}1830,1833 \\
1889\end{array}$ & $\begin{array}{c}\text { AAL, Rep } 60 \\
\text { A } 207, \text { s. } \\
117 \mathrm{v}-118 ; \\
\text { AAL, Rep } 60 \\
\text { IX 1, s. } 64- \\
65,263-264 ; \\
\text { AAL, Rep } 60 \\
\text { IX 3, s. } 537\end{array}$ \\
\hline 34. & Hrubieszów & $\begin{array}{l}\text { Różańcowe } \\
\text { Szkaplerzne }\end{array}$ & 1560 & - & $\begin{array}{c}1816,1833, \\
1889 \\
1889\end{array}$ & $\begin{array}{c}\text { AAL, Rep } 60 \\
\text { A 202, s. } 15 ; \\
\text { AAL, Rep } 60 \\
\text { IX 1, s. } 64- \\
65,263-264 ; \\
\text { AAL, Rep } 60 \\
\text { IX 3, s. } 537 \\
\\
\text { AAL, Rep } 60 \\
\text { IX 3, s. } 537\end{array}$ \\
\hline 35. & Janów & Różańcowe & 1660 & - & 1833,1889 & $\begin{array}{c}\text { AAL, Rep } 60 \\
\text { IX 1, s. } 233 \text {, } \\
267-268 ; \\
\text { AAL, Rep } 60 \\
\text { IX 3, s. } 537\end{array}$ \\
\hline
\end{tabular}




\begin{tabular}{|c|c|c|c|c|c|c|}
\hline 36. & Józefów & $\begin{array}{l}\text { Różańcowe } \\
\text { św. Anny } \\
\text { Św. Trójcy }{ }^{37} \\
\text { Imienia } \\
\text { Jezus } \\
38\end{array}$ & $\begin{array}{c}1741 \\
\\
- \\
- \\
-\end{array}$ & $\begin{array}{c}1741 \\
\\
- \\
- \\
-\end{array}$ & $\begin{array}{c}1817,1830, \\
1833,1889 \\
1817 \\
1833 \\
1833\end{array}$ & $\begin{array}{c}\text { AAL, Rep } 60 \\
\text { A 204, s. 192; } \\
\text { AAL, Rep } 60 \\
\text { A 208, s. } 188 ; \\
\text { AAL, Rep } 60 \\
\text { IX 1, s. } 182, \\
\text { 269-270; } \\
\text { AAL, Rep } 60 \\
\text { IX 3, s. 536v } \\
\text { AAL, Rep } 60 \\
\text { A 204, s. } 192 \\
\\
\text { AAL, Rep } 60 \\
\text { IX 1, s. } 182 \\
\text { AAL, Rep } 60 \\
\text { IX 1, s. } 182\end{array}$ \\
\hline 37. & Kamionka & $\begin{array}{l}\text { Pocieszenia } \\
\text { NMP } \\
\text { Miłosierdzia }^{39}\end{array}$ & $\begin{array}{l}9 \text { I } 1628 \\
\\
\text { koniec } \\
\text { XVIIIw. }\end{array}$ & 15 VI 1628 & $\begin{array}{r}1800,1833, \\
1835,1889 \\
\\
1800,1835\end{array}$ & $\begin{array}{c}\text { AAL, Rep } 60 \\
\text { A } 184, \text { s. } 288 ; \\
\text { AAL, Rep } 60 \\
\text { IX 1, s. 155- } \\
\text { 156, 160-161, } \\
279-280 ; \\
\text { AAL, Rep } 60 \\
\text { A 205, s. } \\
\text { 422v-423; } \\
\text { AAL, Rep } 60 \\
\text { IX 3, s. 537v } \\
\text { AAL, Rep } 60 \\
\text { A 184, s. } 288 ; \\
\text { AAL, Rep } 60 \\
\text { A 205, s. } \\
\text { 422v-423 }\end{array}$ \\
\hline 38. & Karczmiska & Szkaplerzne & $20 \mathrm{VII} 1714^{40}$ & - & $\begin{array}{c}1801,1830 \\
1889\end{array}$ & $\begin{array}{l}\text { AAL, Rep } 60 \\
\text { A } 185, \text { s. } 350 ; \\
\text { AAL, Rep } 60 \\
\text { A 205, s. 26; } \\
\text { AAL, Rep } 60 \\
\text { IX 3, s. 536v }\end{array}$ \\
\hline
\end{tabular}

${ }^{37}$ Informacja o trzech bractwach w parafii: różańcowym, Św. Trójcy, Imienia Jezus, pojawia się tylko w 1833 r. (AAL, Rep 60 IX 1, s. 182).

${ }^{38}$ Informacja o trzech bractwach w parafii: różańcowym, Św. Trójcy, Imienia Jezus, pojawia się tylko w 1833 r. (AAL, Rep 60 IX 1, s. 182).

${ }^{39}$ Bractwo Miłosierdzia zostało połączone razem z bractwem Pocieszenia NMP w jedno (AAL, Rep 60 A 205, s. 160-161).

${ }^{40}$ Według spisu bractw z 1889 roku bractwo to założone zostało w 1713 r., a w 1714 zaaprobował je biskup chełmski Szembek (AAL, Rep 60 IX 3, s. 536v). 


\begin{tabular}{|c|c|c|c|c|c|c|}
\hline 39. & Kazimierz & $\begin{array}{l}\text { Różańcowe } \\
\text { św. Anny }\end{array}$ & 1641 & - & $\begin{array}{c}1801,1827, \\
1830,1833, \\
1889 \\
\\
1833,1889\end{array}$ & $\begin{array}{c}\text { AAL, Rep } 60 \\
\text { A 185, s. 283; } \\
\text { AAL, Rep 60 } \\
\text { V, 2, s. 277v; } \\
\text { AAL, Rep } 60 \\
\text { A 205, s. 9; } \\
\text { AAL, Rep } 60 \\
\text { IX 1, s. 88- } \\
90,107-108, \\
261-262,298 ; \\
\text { AAL, Rep 60 } \\
\text { IX 3, s. 536v } \\
\\
\text { AAL, Rep 60 } \\
\text { IX 1, s. 107- } \\
\text { 108; AAL, } \\
\text { Rep 60 IX 3, } \\
\text { s. 536v }\end{array}$ \\
\hline 40. & Kiełczewice & Szkaplerzne $^{41}$ & 1669 & 27 VII 1669 & $\begin{array}{c}1801,1827, \\
1889\end{array}$ & $\begin{array}{c}\text { AAL, Rep } 60 \\
\text { A } 185, \text { s. } 587 ; \\
\text { AAL, Rep } 60 \\
\text { V, 2, s. } 177 \mathrm{v} ; \\
\text { AAL, Rep } 60 \\
\text { IX 3, s. } 538\end{array}$ \\
\hline 41. & Kijany & Szkaplerzne & 1730 & - & $\begin{array}{c}1800,1835 \\
1889\end{array}$ & $\begin{array}{l}\text { AAL, Rep } 60 \\
\text { A 184, s. } 475 ; \\
\text { AAL, Rep } 60 \\
\text { A 205, s. } 460 ; \\
\text { AAL, Rep } 60 \\
\text { IX 3, s. 537v }\end{array}$ \\
\hline 42. & $\begin{array}{l}\text { Klementowi- } \\
\text { ce }\end{array}$ & Różańcowe & 6 IV 1814 & 1814 & $\begin{array}{l}1827,1830 \\
1834,1889\end{array}$ & $\begin{array}{c}\text { AAL, Rep } 60 \\
\text { V, 2, s. 274; } \\
\text { AAL, Rep } 60 \\
\text { A 205, s. 212; } \\
\text { AAL, Rep } 60 \\
\text { IX 1, s. } 94- \\
\text { 95, 279-280; } \\
\text { AAL, Rep } 60 \\
\text { IX 3, s. 536v }\end{array}$ \\
\hline 43. & Kluczkowice & Św. Trójcy & - & - & 1889 & $\begin{array}{l}\text { AAL, Rep } 60 \\
\text { IX 3, s. 536v }\end{array}$ \\
\hline 44. & Kłoczów & Różańcowe & - & - & 1808,1889 & $\begin{array}{l}\text { AAL, Rep } 60 \\
\text { A 197, s. 40; } \\
\text { AAL, Rep } 60 \\
\text { IX 3, s. 538v }\end{array}$ \\
\hline
\end{tabular}

${ }^{41}$ Według spisu bractw w 1889 r. bractwo już nie istniało, chociaż nadal posiadało w banku pewien kapitał, od którego „Bractwo pobiera procent każdego roku” (AAL, Rep 60 IX 3, s. 538). 


\begin{tabular}{|c|c|c|c|c|c|c|}
\hline 45. & Kock & $\begin{array}{l}\text { Różańcowe i } \\
\text { Miłosierdzia }^{42}\end{array}$ & $\begin{array}{l}1728 \\
1785\end{array}$ & $\begin{array}{l}- \\
-\end{array}$ & $\begin{array}{c}1807,1889 \\
1807\end{array}$ & $\begin{array}{c}\text { AAL, Rep } 60 \\
\text { A 196a, s. 59, } \\
\text { 79v82; AAL, } \\
\text { Rep } 60 \text { IX 3, } \\
\text { s. } 539\end{array}$ \\
\hline 46. & Końskowola & $\begin{array}{c}\text { Różańcowe } \\
\text { Niepokalane- } \\
\text { go Poczęcia } \\
\text { NMP }^{43}\end{array}$ & $\begin{array}{l}20 \mathrm{~V} 1668 \\
6 \mathrm{IV} 1693^{44}\end{array}$ & 16 XII 1669 & $\begin{array}{c}1801,1833 \\
1889\end{array}$ & $\begin{array}{c}\text { AAL, Rep } 60 \\
\text { A 185, s. } 425 ; \\
\text { AAL, Rep } 60 \\
\text { IX 1, s. } 93 \text {, } \\
\text { 109-110, 261- } \\
\text { 262, } 298 \\
\\
\text { AAL, Rep } 60 \\
\text { IX 3, s. 536v }\end{array}$ \\
\hline 47. & Kossów & Różańcowe & 1660 & - & 1808 & $\begin{array}{c}\text { AAL, Rep } 60 \\
\text { A } 198 \text {, s. } 60 \\
\end{array}$ \\
\hline 48. & Krasienin & $\begin{array}{c}\text { Najświętszego } \\
\text { Sakramentu } \\
\text { Miłosierdzia }\end{array}$ & $\begin{array}{c}1767 \\
13 \text { VIII } 1782\end{array}$ & $\begin{array}{l}- \\
-\end{array}$ & $\begin{array}{c}1800,1889 \\
1800\end{array}$ & $\begin{array}{l}\text { AAL, Rep } 60 \\
\text { A 184, s. 351; } \\
\text { AAL, Rep 60 } \\
\text { IX 3, s. 537v } \\
\text { AAL, Rep } 60 \\
\text { A 184, s. } 352 \\
\end{array}$ \\
\hline 49. & Krasnobród & Różańcowe & 1684 & 1700 & $\begin{array}{c}1817,1832 \\
1889\end{array}$ & $\begin{array}{l}\text { AAL, Rep } 60 \\
\text { A 203, s. 150; } \\
\text { AAL, Rep 60 } \\
\text { A 207, s. 69v; } \\
\text { AAL, Rep 60 } \\
\text { IX 3, s. } 538\end{array}$ \\
\hline
\end{tabular}

${ }^{42}$ Wcześniej osobno funkcjonowało bractwo różańcowe założone w 1728 r. (Flaga, Bractwa religijne $w$ archidiakonacie lubelskim, s. 308-309) i bractwo Miłosierdzia założone w 1785 roku (AAL, Rep 60 A 196a, s. 59). W 1807 r. funkcjonują jako połączone w jedno.

${ }^{43}$ Wprawdzie nie ma informacji na temat tego bractwa w I poł. XIX wieku, ale funkcjonowało w 1748 r. (zob. Flaga, Bractwa religijne w archidiakonacie lubelskim, s. 308-309) i w 1888 r. (AAL, Rep 60 IX 3, s. 536v).

${ }^{44}$ J. Flaga podaje, że bractwo to zostało wprowadzone 7 X 1693 r. (Flaga, Bractwa religijne $w$ archidiakonacie lubelskim, s. 308). 


\begin{tabular}{|c|c|c|c|c|c|c|}
\hline 50. & Krasnystaw & $\begin{array}{c}\text { Różańcowe } \\
\text { Szkaplerzne } \\
\\
\text { Jezusa } \\
\text { Miłosiernego } \\
\text { (Konających) }\end{array}$ & $\begin{array}{c}6 \text { X } 1799^{45} \\
18 \text { VII } 1790^{46} \\
8 \text { I } 1755\end{array}$ & - & $\begin{array}{c}1827,1833, \\
1889 \\
\\
1827,1833, \\
1889 \\
\\
1833,1889\end{array}$ & $\begin{array}{c}\text { AAL, Rep } 60 \\
\text { V, 2, s. 101v, } \\
\text { 103; AAL, } \\
\text { Rep } 60 \text { IX 1, } \\
\text { s. 124-125, } \\
\text { 271-272; } \\
\text { AAL, Rep } 60 \\
\text { IX 3, s. 537v } \\
\\
\text { AAL, Rep } 60 \\
\text { V, 2, s. 101v, } \\
\text { 103; AAL, } \\
\text { Rep 60 IX 1, } \\
\text { s. 124-125, } \\
271-272 ; \\
\text { AAL, Rep } 60 \\
\text { IX 3, s. 537v } \\
\\
\text { AAL, Rep } 60 \\
\text { IX 1, s. 124- } \\
\text { 125, 271-272; } \\
\text { AAL, Rep } 60 \\
\text { IX 3, s. 537v }\end{array}$ \\
\hline 51. & Kraśnik & Różańcowe & $1736^{47}$ & - & $\begin{array}{c}1801,1833, \\
1889\end{array}$ & $\begin{array}{c}\text { AAL, Rep } 60 \\
\text { A 186, s. 166; } \\
\text { AAL, Rep } 60 \\
\text { IX 1, s. 214, } \\
\text { 265-266; } \\
\text { AAL, Rep } 60 \\
\text { IX 3, s. } 537\end{array}$ \\
\hline 52. & Krężnica & Różańcowe & - & - & 1889 & $\begin{array}{c}\text { AAL, Rep } 60 \\
\text { IX 3, s. } 536\end{array}$ \\
\hline 53. & Kryłów & Św. Trójcy & - & - & $\begin{array}{l}1830 \\
1833^{48}\end{array}$ & $\begin{array}{c}\text { AAL, Rep } 60 \\
\text { A 207, s. } \\
\text { 135v; AAL, } \\
\text { Rep } 60 \text { IX 1, } \\
\text { s. } 64-65\end{array}$ \\
\hline
\end{tabular}

${ }^{45}$ Według spisu bractw z 1889 r. zostało ono założone w 1717 r. (AAL, Rep 60 IX 3, s. 537v).

${ }^{46}$ Według spisu bractw z 1889 r. zostało ono założone w 1717 r. (AAL, Rep 60 IX 3, s. 537v).

${ }^{47}$ Bractwo istniało dużo wcześniej, lecz zaginęły dokumenty i w 1736 r. zostało oficjalnie odnowione (AAL, Rep 60 IX 1, s. 214, 265-266).

${ }^{48}$ Bractwo jako takie już nie istniało, ale pod przewodnictwem proboszcza zbierano się w niedziele i święta żeby śpiewać koronkę (AAL, Rep 60 IX 1, s. 64-65). 


\begin{tabular}{|c|c|c|c|c|c|c|}
\hline 54. & Krzczonów & Różańcowe & 15 VIII 1653 & - & $\begin{array}{c}1800,1804 \\
1833\end{array}$ & $\begin{array}{c}\text { AAL, Rep } 60 \\
\text { A 182, s. 175; } \\
\text { AAL, Rep } 60 \\
\text { A } 188, \text { s. } \\
\text { 183v; AAL, } \\
\text { Rep } 60 \text { IX 1, } \\
\text { s. 140, 277- } \\
278\end{array}$ \\
\hline 55. & Księżomierz & Różańcowe & 1862 & - & 1889 & $\begin{array}{c}\text { AAL, Rep } 60 \\
\text { IX 3, s. } 537\end{array}$ \\
\hline 56. & Kumów & Różańcowe & $10 \mathrm{~V} 1719$ & - & 1833,1889 & $\begin{array}{c}\text { AAL, Rep } 60 \\
\text { IX 1, s. } 28 \\
271-272,300 ; \\
\text { AAL, Rep } 60 \\
\text { IX 3, s. } 537\end{array}$ \\
\hline 57. & Kurów & $\begin{array}{c}\text { Różańcowe } \\
\text { św. Jana } \\
\text { Nepomucena } \\
\text { Miłosierdzia9 }\end{array}$ & $\begin{array}{c}2 \text { VIII } 1669 \\
1763 \\
1788\end{array}$ & $25 \times 1763$ & $\begin{array}{c}1800,1803, \\
1827,1830, \\
1833,1889 \\
1800,1803, \\
1830 \\
\\
1800,1803, \\
1827,1830\end{array}$ & $\begin{array}{c}\text { AAL, Rep } 60 \\
\text { A 183, s. 63v; } \\
\text { AAL, Rep } 60 \\
\text { A 190, s. 15; } \\
\text { AAL, Rep } 60 \\
\text { V, 2, s. 257; } \\
\text { AAL, Rep } 60 \\
\text { A 205, s. } \\
\text { 180v; AAL, } \\
\text { Rep 60 IX 1, } \\
\text { s. 109-110, } \\
\text { 261-262; } \\
\text { AAL, Rep } 60 \\
\text { IX 3, s. 536v } \\
\text { AAL, Rep 60 } \\
\text { A 183, s. 63v; } \\
\text { AAL, Rep } 60 \\
\text { A 190, s. 15; } \\
\text { AAL, Rep } 60 \\
\text { A 205, s. } \\
\text { 180v } \\
\text { AAL, Rep 60 } \\
\text { A 183, s. 63v; } \\
\text { AAL, Rep 60 } \\
\text { A 190, s. 15, } \\
78-79 ; \text { AAL, } \\
\text { Rep 60 V, 2, } \\
\text { s. 257-258; } \\
\text { AAL, Rep 60 } \\
\text { A 205, s. } \\
\text { 180v-181 }\end{array}$ \\
\hline
\end{tabular}

${ }^{49}$ Mowa jest jeszcze o tym bractwie w 1827 i 1830 roku, ale już w formie przeszłej. Ze względów finansowych bractwo to przestało istnieć około 1810 r. (AAL, Rep 60 V, 2, s. 257-258; AAL, Rep 60 A 205, s. 181). 


\begin{tabular}{|c|c|c|c|c|c|c|}
\hline 58. & Lubartów & $\begin{array}{c}\text { Różańcowe } \\
\\
\text { św. Jana } \\
\text { Nepomucena } \\
\text { św. Anny }\end{array}$ & 15 VIII 1714 & 1760 & $\begin{array}{l}1800,1833, \\
1835,1889 \\
1800,1835 \\
1800,1835\end{array}$ & $\begin{array}{c}\text { AAL, Rep 60 } \\
\text { A 184, s. 197; } \\
\text { AAL, Rep IX } \\
\text { 1, s. 155-156, } \\
\text { 160-161, 279- } \\
\text { 280; AAL, } \\
\text { Rep 60 A 205, } \\
\text { s. 437v; AAL, } \\
\text { Rep } 60 \text { IX 3, } \\
\text { s. 537v } \\
\text { AAL, Rep } 60 \\
\text { A 184, s. 197; } \\
\text { AAL, Rep } 60 \\
\text { A 205, s. } \\
\text { 437v } \\
\text { AAL, Rep } 60 \\
\text { A 184, s. 197; } \\
\text { AAL, Rep } 60 \\
\text { A 205, s. } \\
\text { 437v }\end{array}$ \\
\hline 59. & $\begin{array}{c}\text { Lublin } \\
\text { (Augustianie) } \\
\text { Kalinow- } \\
\text { szczyzna }\end{array}$ & $\begin{array}{l}\text { Pocieszenia } \\
\text { NMP }\end{array}$ & 30 XII $1661^{50}$ & 29 VI 1668 & 1865,1889 & $\begin{array}{c}\text { AAL, Rep } 60 \\
\text { IX 1, s. } 359- \\
\text { 360; AAL, } \\
\text { Rep } 60 \text { IX 3, } \\
\text { s. } 536\end{array}$ \\
\hline
\end{tabular}

${ }^{50}$ Według J. Flagi bractwo to zostało wprowadzone w 1659 roku (Flaga, Bractwa religijne $w$ archidiakonacie lubelskim, s. 316). 


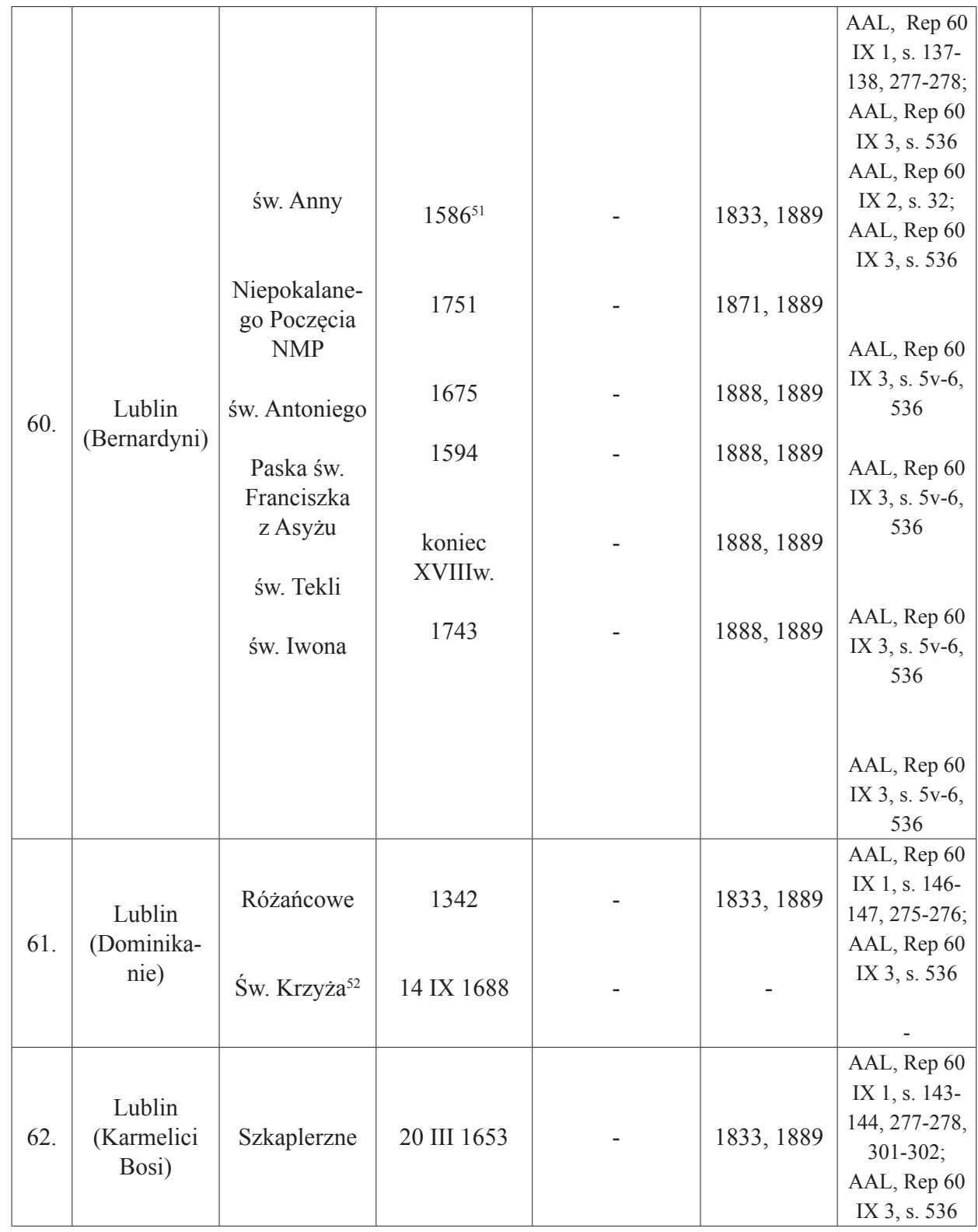

${ }^{51}$ Trudno jest ustalić rzeczywistą datę założenia tego bractwa w Lublinie. W roku 1586 bractwo to uzyskało zatwierdzenie papieża Sykstusa V na całe Królestwo Polskie. W źródłach jako data założenia tego bractwa pojawia się również rok 1460 i 1752 (AAL, Rep 60 IX 1, s. 137-138, 277-278, $362)$.

${ }^{52} \mathrm{~W}$ sprawozdaniach XIX-wiecznych sporządzanych przez duchowieństwo nie ma mowy o tym bractwie, jednak inne źródła wskazują na jego funkcjonowanie w XIX wieku (zob. Flaga, Bractwa religijne w archidiakonacie lubelskim, s. 312-313). 


\begin{tabular}{|c|c|c|c|c|c|c|}
\hline 63. & $\begin{array}{l}\text { Lublin } \\
\text { (katedra) }\end{array}$ & Św. Trójcy & 4 VII 1727 & 1727 & 1833,1889 & $\begin{array}{c}\text { AAL, Rep } 60 \\
\text { IX 1, s. } 153 \text {, } \\
275-276 ; \\
\text { AAL, Rep } 60 \\
\text { IX 3, s. } 536\end{array}$ \\
\hline 64. & $\begin{array}{c}\text { Lublin } \\
\text { (Św. Ducha) }\end{array}$ & $\begin{array}{l}\text { Imienia Maryi } \\
\text { Serca Maryi }^{53}\end{array}$ & $\begin{array}{l}12 \text { IX } 1739 \\
13 \times 1856\end{array}$ & - & $\begin{array}{l}1833 \\
1889\end{array}$ & $\begin{array}{c}\text { AAL, Rep } 60 \\
\text { IX 1, s. } 149- \\
\text { 150, 275-276, } \\
303 \\
\text { AAL, Rep } 60 \\
\text { IX 1, s. } 352 ; \\
\text { AAL, Rep } 60 \\
\text { IX 3, s. } 536\end{array}$ \\
\hline 65. & $\begin{array}{c}\text { Lublin } \\
\text { (Wizytki) }\end{array}$ & $\begin{array}{l}\text { Serca Jezuso- } \\
\text { wego }\end{array}$ & 1723 & - & 1865 & $\begin{array}{c}\text { AAL, Rep } 60 \\
\text { IX 1, s. 355- } \\
356 \\
\end{array}$ \\
\hline 66. & Łabunie & $\begin{array}{l}\text { Różańcowe } \\
\text { Szkaplerzne }\end{array}$ & 1751 & - & $\begin{array}{c}1817,1832, \\
1889 \\
1817,1832, \\
1889\end{array}$ & $\begin{array}{c}\text { AAL, Rep } 60 \\
\text { A 203, s. 249; } \\
\text { AAL, Rep } 60 \\
\text { A 207, s. 50v; } \\
\text { AAL, Rep } 60 \\
\text { IX 3, s. } 538 \\
\text { AAL, Rep } 60 \\
\text { A 203, s. 249; } \\
\text { AAL, Rep } 60 \\
\text { A 207, s. 50v; } \\
\text { AAL, Rep } 60 \\
\text { IX 3, s. } 538\end{array}$ \\
\hline 67. & Łaskarzew & $\begin{array}{c}\text { Matki Boskiej } \\
\text { z } \\
\text { Góry Karmel } \\
\text { (szkaplerzne) }\end{array}$ & 1746 & - & 1808 & $\begin{array}{c}\text { AAL, Rep } 60 \\
\text { A 197, s. } \\
166 \mathrm{v}\end{array}$ \\
\hline 68. & Łaszczów & Różańcowe & 5 IX 1751 & - & $\begin{array}{c}1830,1833, \\
1889\end{array}$ & $\begin{array}{c}\text { AAL, Rep } 60 \\
\text { A 208, s. } 278 ; \\
\text { AAL, Rep } 60 \\
\text { IX 1, s. 190, } \\
\text { 192, 269-270; } \\
\text { AAL, Rep } 60 \\
\text { IX 3, s. } 538\end{array}$ \\
\hline
\end{tabular}

${ }^{53}$ Bractwo początkowo zostało utworzone przy kościele kapucynów, następnie przeniesione do kościoła Sióstr Miłosierdzia i w końcu do kościoła Św. Ducha (AAL, Rep 60 IX 1, s. 352). 


\begin{tabular}{|c|c|c|c|c|c|c|}
\hline 69. & Łęczna & $\begin{array}{l}\text { Bożego Ciała } \\
\text { Różańcowe }\end{array}$ & $\begin{array}{c}1577-1618^{54} \\
\text { ok. } 1618^{55}\end{array}$ & $\begin{array}{r}1639 \\
-\end{array}$ & $\begin{array}{l}1800,1830 \\
1833,1889 \\
1800,1830 \\
1833,1889\end{array}$ & $\begin{array}{c}\text { AAL, Rep } 60 \\
\text { A } 184, \text { s. } 696 ; \\
\text { AAL, Rep } 60 \\
\text { A 206, s. } 123 ; \\
\text { AAL, Rep } 60 \\
\text { IX 1, s. 20, } \\
\text { 23, 304; } \\
\text { AAL, Rep } 60 \\
\text { IX 3, s. } 537 \mathrm{v} \\
\text { AAL, Rep } 60 \\
\text { A 184, s. } 696 ; \\
\text { AAL, Rep } 60 \\
\text { A 206, s. } 123 ; \\
\text { AAL, Rep } 60 \\
\text { IX 1, s. 20, } \\
23,304 ; \\
\text { AAL, Rep } 60 \\
\text { IX 3, s. } 537 \mathrm{v}\end{array}$ \\
\hline 70. & Łukowa & św. Anny & 1612 & 1612 & $\begin{array}{c}1817,1830 \\
1889\end{array}$ & $\begin{array}{c}\text { AAL, Rep } 60 \\
\text { A 204, s. } \\
\text { 176v; AAL, } \\
\text { Rep } 60 \text { A } 208 \text {, } \\
\text { s. 141v; AAL, } \\
\text { Rep } 60 \text { IX } 3 \text {, } \\
\text { s. } 538\end{array}$ \\
\hline 71. & Łuszczów & św. Barbary & 9 VI 1743 & - & 1800,1835 & $\begin{array}{c}\text { AAL, Rep } 60 \\
\text { A } 184, \text { s. } 545 ; \\
\text { AAL, Rep } 60 \\
\text { A 205, s. } \\
\quad 471 \mathrm{v}\end{array}$ \\
\hline 72. & Łysoboki & Miłosierdzia & $\begin{array}{l}\text { koniec } \\
\text { XVIIIw. }\end{array}$ & - & 1807 & $\begin{array}{c}\text { AAL, Rep } 60 \\
\text { A 196a, s. } \\
47 \mathrm{v}\end{array}$ \\
\hline 73. & Maciejowice & Różańcowe & 1681 & - & 1808,1889 & $\begin{array}{l}\text { AAL, Rep } 60 \\
\text { A 197, s. } 215 ; \\
\text { AAL, Rep } 60 \\
\text { IX 3, s. } 538 \mathrm{v}\end{array}$ \\
\hline
\end{tabular}

${ }^{54} \mathrm{~W}$ źródłach funkcjonują różne daty określające wprowadzenie tego bractwa w parafii. Najwcześniejszą jest rok 1577 (AAL, Rep 60 IX 3, s. 537v), drugą jest rok 1618 (AAL, Rep 60 IX , s. 20, 23, 304), w 1639 r. bractwo uzyskało przywilej od papieża Urbana VIII (AAL, Rep 60 IX 3, s. $537 \mathrm{v})$.

${ }^{55}$ Wykaz z 1889 roku informuje, że bractwo to zostało wprowadzone w 1659 r. (AAL, Rep 60 IX 3, s. $537 \mathrm{v})$. 


\begin{tabular}{|c|c|c|c|c|c|c|}
\hline 74. & Markuszów & $\begin{array}{l}\text { Św. Trójcy } \\
\text { św. Anny }\end{array}$ & $\begin{array}{r}1788 \\
1793\end{array}$ & - & $\begin{array}{l}1830,1833 \\
1800,1803, \\
1830,1833\end{array}$ & 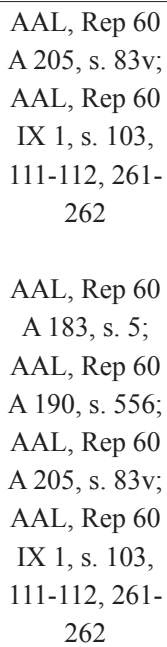 \\
\hline 75. & Mełgiew & $\begin{array}{c}\text { św. Jana } \\
\text { Nepomucena }\end{array}$ & 1730 & 25 IX 1826 & $\begin{array}{c}1800,1833, \\
1889\end{array}$ & $\begin{array}{c}\text { AAL, Rep } 60 \\
\text { A } 184, \text { s. } 580 ; \\
\text { AAL, Rep } 60 \\
\text { IX 1, s. } 155- \\
\text { 156, 157, } \\
279-280,306 ; \\
\text { AAL, Rep } 60 \\
\text { IX 3, s. } 536\end{array}$ \\
\hline 76. & Michów & Różańcowe & 1732 & - & 1803,1889 & $\begin{array}{l}\text { AAL, Rep } 60 \\
\text { A 190, s. 194; } \\
\text { AAL, Rep } 60 \\
\text { IX 3, s. 537v }\end{array}$ \\
\hline 77. & Miedzna & Różańcowe & - & - & 1808,1889 & $\begin{array}{c}\text { AAL, Rep } 60 \\
\text { A 198, s. } 127 ; \\
\text { AAL, Rep } 60 \\
\text { IX 3, s. } 540\end{array}$ \\
\hline 78. & Milejów & Różańcowe & 1862 & - & 1889 & $\begin{array}{c}\text { AAL, Rep } 60 \\
\text { IX 3, s. } 537\end{array}$ \\
\hline 79. & $\begin{array}{l}\text { Modliborzy- } \\
\text { ce }\end{array}$ & Różańcowe & 19 III 1706 & - & $\begin{array}{l}1801,1814, \\
1833,1889\end{array}$ & $\begin{array}{c}\text { AAL, Rep } 60 \\
\text { A 186, s. } 838 ; \\
\text { AAL, Rep } 60 \\
\text { A } 199, \text { s. } 32 ; \\
\text { AAL, Rep } 60 \\
\text { IX 1, s. 230- } \\
\text { 231, 267-268, } \\
\text { 306; AAL, } \\
\text { Rep } 60 \text { IX 3, } \\
\text { s. } 537\end{array}$ \\
\hline
\end{tabular}




\begin{tabular}{|c|c|c|c|c|c|c|}
\hline 80. & Mokobrody & Różańcowe & 1738 & - & 1808,1889 & $\begin{array}{l}\text { AAL, Rep } 60 \\
\text { A 198, s. } 49 ; \\
\text { AAL, Rep } 60 \\
\text { IX 3, s. 539v }\end{array}$ \\
\hline 81. & Mokrelipie & Św. Trójcy & - & - & 1817 & $\begin{array}{c}\text { AAL, Rep } 60 \\
\text { A 204, s. } \\
202 \mathrm{v}\end{array}$ \\
\hline 82. & Nabroż & Szkaplerzne & 1708 & - & 1830 & $\begin{array}{c}\text { AAL, Rep } 60 \\
\text { A 208, s. } \\
255 \mathrm{v}\end{array}$ \\
\hline 83. & Niedrzwica & Różańcowe & 1608 & - & 1888,1889 & $\begin{array}{c}\text { AAL, Rep } 60 \\
\text { IX 3, s. } 8 \mathrm{v}-9 \text {, } \\
536\end{array}$ \\
\hline 84. & Nielisz & Różańcowe & - & - & 1832 & $\begin{array}{c}\text { AAL, Rep } 60 \\
\text { A 207, s. } \\
105 \mathrm{v}\end{array}$ \\
\hline 85. & Niwiska & Różańcowe & 13 III 1760 & - & 1870,1889 & $\begin{array}{l}\text { AAL, Rep } 60 \\
\text { IX 2, s. 7-10; } \\
\text { AAL, Rep 60 } \\
\text { IX 3, s. 539v }\end{array}$ \\
\hline 86. & Olchowiec & Miłosierdzia & 1 XI 1830 & - & 1833 & $\begin{array}{c}\text { AAL, Rep } 60 \\
\text { IX 1, s. } 24 \text {, } \\
40-41,273- \\
274,306\end{array}$ \\
\hline 87. & Opole & Różańcowe & 1617 & 1743 & $\begin{array}{c}1801,1827, \\
1830,1833, \\
1889\end{array}$ & $\begin{array}{c}\text { AAL, Rep } 60 \\
\text { A 185, s. 107; } \\
\text { AAL, Rep } 60 \\
\text { V, 2, s. 181v; } \\
\text { AAL, Rep } 60 \\
\text { A 205, s. } \\
\text { 265v; AAL, } \\
\text { Rep 60 IX 1, } \\
\text { s. 54-55, 277- } \\
278,308 ; \\
\text { AAL, Rep 60 } \\
\text { IX 3, s. 536v }\end{array}$ \\
\hline 88. & Orchówek & $\begin{array}{c}\text { Pocieszenia } \\
\text { NMP } \\
\text { św. Tekli } \\
\text { św. Antoniego } \\
\text { z Padwy }\end{array}$ & - & - & $\begin{array}{r}1804 \\
1804 \\
1804\end{array}$ & $\begin{array}{c}\text { AAL, Rep } 60 \\
\text { A } 192, \text { s. } 4 \mathrm{v} \\
\\
\text { AAL, Rep } 60 \\
\text { A 192, s. 4v } \\
\text { AAL, Rep } 60 \\
\text { A 192, s. 4v }\end{array}$ \\
\hline
\end{tabular}




\begin{tabular}{|c|c|c|c|c|c|c|}
\hline 89. & Ostrów & Różańcowe & 1761 & - & 1800,1889 & $\begin{array}{l}\text { AAL, Rep } 60 \\
\text { A 184, s. } 6 \text {; } \\
\text { AAL, Rep } 60 \\
\text { IX 3, s. } 540\end{array}$ \\
\hline 90. & Oszczów & Św. Trójcy & 1773 & - & 1889 & $\begin{array}{c}\text { AAL, Rep } 60 \\
\text { IX 3, s. } 538\end{array}$ \\
\hline 91. & Parczew & $\begin{array}{l}\text { Różańcowe } \\
\text { Miłosierdzia }\end{array}$ & $\begin{array}{l}1811^{33} \\
\text { koniec } \\
\text { XVIIIw. }\end{array}$ & $\begin{array}{c}1812 \\
-\end{array}$ & $\begin{array}{c}1800,1889 \\
1800\end{array}$ & $\begin{array}{c}\text { AAL, Rep } 60 \\
\text { A } 184, \text { s. } 63 ; \\
\text { AAL, Rep } 60 \\
\text { IX } 3, \text { s. } 540 \\
\text { AAL, Rep } 60 \\
\text { A } 184, \text { s. } 63\end{array}$ \\
\hline 92. & Pawłowice & Różańcowe & 1701 & - & 1808,1889 & $\begin{array}{c}\text { AAL, Rep } 60 \\
\text { A 197, s. } \\
273 \mathrm{v} ; \text { AAL, } \\
\text { Rep } 60 \text { IX } 3, \\
\text { s. } 538 \mathrm{v}\end{array}$ \\
\hline 93. & Pawłów & Różańcowe & 28 IV 1792 & - & 1833,1834 & $\begin{array}{c}\text { AAL, Rep } 60 \\
\text { IX 1, s. 31- } \\
32,37,273- \\
274,308\end{array}$ \\
\hline 94. & Piaski & Różańcowe & $1743^{34}$ & - & $\begin{array}{c}1800,1804 \\
1889\end{array}$ & $\begin{array}{c}\text { AAL, Rep } 60 \\
\text { A } 182, \text { s. } 86 ; \\
\text { AAL, Rep } 60 \\
\text { A } 188, \text { s. } \\
\text { 262v; AAL, } \\
\text { Rep } 60 \text { IX } 3 \text {, } \\
\text { s. } 536\end{array}$ \\
\hline 95. & Piotrawin & Różańcowe & 10 I 1808 & - & $\begin{array}{c}1830,1833 \\
1889\end{array}$ & $\begin{array}{c}\text { AAL, Rep } 60 \\
\text { A 205, s. } 243 ; \\
\text { AAL, Rep } 60 \\
\text { IX 1, s. } 60 \\
277-278,308 ; \\
\text { AAL, Rep } 60 \\
\text { IX 3, s. 536v }\end{array}$ \\
\hline 96. & Popkowice & Św. Trójcy & - & - & 1801 & $\begin{array}{l}\text { AAL, Rep } 60 \\
\text { A } 186, \text { s. } 272\end{array}$ \\
\hline
\end{tabular}

${ }^{56}$ Bractwo to istniało dużo wcześniej, bo w źródłach znajdują się informacje, że zatwierdzone zostało na początku XVII wieku (Flaga, Bractwa religijne $w$ archidiakonacie lubelskim, s. 320), znajduje się też o nim informacja w wizytacji z 1800 r. Prawdopodobnie więc bractwo to zostało odnowione i ponownie zatwierdzone w 1812 r. przez biskupa Skarszewskiego (AAL, Rep 60 IX 3, s. 540).

${ }^{57} \mathrm{~W}$ spisie z 1889 r. jako data wprowadzenia tego bratwa podany jest rok 1735 (AAL, Rep 60 IX 3, s. 536). 


\begin{tabular}{|c|c|c|c|c|c|c|}
\hline 97. & Potok & $\begin{array}{l}\text { Różańcowe } \\
\text { Szkaplerzne } \\
\text { Św. Trójcy }\end{array}$ & $\begin{array}{l}1711 \\
1677 \\
1751\end{array}$ & - & $\begin{array}{c}1801,1814, \\
1833,1889 \\
\\
1817,1830, \\
1889 \\
1801\end{array}$ & $\begin{array}{c}\text { AAL, Rep } 60 \\
\text { A 186, s. } 799 ; \\
\text { AAL, Rep } 60 \\
\text { A 199, s. 46; } \\
\text { AAL, Rep } 60 \\
\text { A 208, s. } \\
\text { 154v; AAL, } \\
\text { Rep } 60 \text { IX 1, } \\
\text { s. 224, 244, } \\
267-268,308 ; \\
\text { AAL, Rep } 60 \\
\text { IX 3, s. } 537 \\
\text { AAL, Rep } 60 \\
\text { A 204, s. } \\
\text { 154v; AAL, } \\
\text { Rep 60 A 208, } \\
\text { s. 96; AAL, } \\
\text { Rep 60 IX } 3, \\
\text { s. } 536 \mathrm{v} \\
\text { AAL, Rep } 60 \\
\text { A 186, s. } 799\end{array}$ \\
\hline 98. & Prawno & Św. Anny & - & - & $\begin{array}{c}1801,1806, \\
1814,1827, \\
1830\end{array}$ & $\begin{array}{c}\text { AAL, Rep } 60 \\
\text { A } 186, \text { s. } 493 ; \\
\text { AAL, Rep } 60 \\
\text { A } 195, \text { s. } 4 ; \\
\text { AAL, Rep } 60 \\
\text { A } 199, \text { s. } 70 ; \\
\text { AAL, Rep } 60 \\
\text { V, 2, s. } 186 ; \\
\text { AAL, Rep } 60 \\
\text { A 205, s. } 321\end{array}$ \\
\hline 99. & Puchaczów & Różańcowe & 1684 & - & $\begin{array}{l}1800,1830, \\
1833,1889\end{array}$ & $\begin{array}{c}\text { AAL, Rep } 60 \\
\text { A } 184, \text { s. } 775 ; \\
\text { AAL, Rep } 60 \\
\text { A 206, s. } 168 ; \\
\text { AAL, Rep } 60 \\
\text { IX 1, s. } 19, \\
25,273-274, \\
\text { 308; AAL, } \\
\text { Rep } 60 \text { IX } 3 \text {, } \\
\text { s. } 537\end{array}$ \\
\hline 100. & $\begin{array}{c}\text { Puszcza } \\
\text { Solska }\end{array}$ & Różańcowe & 28 IX 1699 & - & $\begin{array}{l}1801,1830 \\
1833,1889\end{array}$ & $\begin{array}{c}\text { AAL, Rep } 60 \\
\text { A } 186, \text { s. } 948 ; \\
\text { AAL, Rep } 60 \\
\text { A } 208, \text { s. } 65 ; \\
\text { AAL, Rep } 60 \\
\text { IX 1, s. } 183 \text {, } \\
\text { 169, 269-270, } \\
\text { 310; AAL, } \\
\text { Rep } 60 \text { IX 3, } \\
\text { s. } 536 \mathrm{v}\end{array}$ \\
\hline
\end{tabular}




\begin{tabular}{|c|c|c|c|c|c|c|}
\hline 101. & Rachanie & Różańcowe & 19 XI 1752 & - & $\begin{array}{c}1830,1833, \\
1834\end{array}$ & $\begin{array}{c}\text { AAL, Rep } 60 \\
\text { A 208, s. } \\
\text { 364v; AAL, } \\
\text { Rep 60 IX 1, } \\
\text { s. 191, 193, } \\
269-270\end{array}$ \\
\hline 102. & Radecznica & św. Anny & 17 IX 1677 & - & 1833 & $\begin{array}{c}\text { AAL, Rep } 60 \\
\text { IX 1, s. 184, } \\
185,279-280 \text {, } \\
310\end{array}$ \\
\hline 103. & Radoryż & $\begin{array}{l}\text { św. Anny } \\
\text { Różańcowe }\end{array}$ & $\begin{array}{c}1695 \\
-\end{array}$ & $\begin{array}{c}25 \text { VII } 1695 \\
-\end{array}$ & $\begin{array}{l}1807 \\
1889\end{array}$ & $\begin{array}{c}\text { AAL, Rep } 60 \\
\text { A 196a, s. } \\
\text { 131v } \\
\text { AAL, Rep } 60 \\
\text { IX 3, s. } 539\end{array}$ \\
\hline 104. & Radzięcin & Miłosierdzia & $\begin{array}{l}\text { koniec } \\
\text { XVIIIw. }\end{array}$ & - & 1801 & $\begin{array}{c}\text { AAL, Rep } 60 \\
\text { A 186, s. } \\
1024 \\
\end{array}$ \\
\hline 105. & $\begin{array}{l}\text { Rozbity Ka- } \\
\text { mień }\end{array}$ & $\begin{array}{l}\text { Św. Trójcy } \\
\text { Szkaplerzne }\end{array}$ & $\begin{array}{l}- \\
-\end{array}$ & $\begin{array}{l}- \\
-\end{array}$ & $\begin{array}{l}1808 \\
1808\end{array}$ & $\begin{array}{c}\text { AAL, Rep } 60 \\
\text { A } 198, \text { s. } 12 \\
\text { AAL, Rep } 60 \\
\text { A } 198, \text { s. } 12 \\
\end{array}$ \\
\hline 106. & Rudno & Św. Trójcy & 15 VI $1768^{58}$ & 1804 & $\begin{array}{c}1800,1833, \\
1889\end{array}$ & $\begin{array}{c}\text { AAL, Rep } 60 \\
\text { A 184, s. } 311 ; \\
\text { AAL, Rep } 60 \\
\text { IX 1, s. 155- } \\
\text { 156, 160-161, } \\
\text { 279-280, } 310 ; \\
\text { AAL, Rep } 60 \\
\text { IX 3, s. } 538\end{array}$ \\
\hline
\end{tabular}

${ }^{58} \mathrm{~W}$ spisie z 1889 r. jako data wprowadzenia tego bractwa podany jest rok 1771 (AAL, Rep 60 IX 3, s. 538), rok 1771 jako datę erekcji tego bractwa podaje J. Flaga (Flaga, Bractwa religijne w archidiakonacie lubelskim, s. 322). 


\begin{tabular}{|c|c|c|c|c|c|c|}
\hline 107. & Rybitwy & Szkaplerzne & 1623 & 16 VI 1742 & $\begin{array}{c}1801,1806, \\
1814,1827, \\
1830,1833, \\
1889\end{array}$ & $\begin{array}{c}\text { AAL, Rep } 60 \\
\text { A 186, s. 464; } \\
\text { AAL, Rep 60 } \\
\text { A 195, s. 26v; } \\
\text { AAL, Rep } 60 \\
\text { A 189, s. } 389 ; \\
\text { AAL, Rep } 60 \\
\text { A 199, s. 3; } \\
\text { AAL, Rep } 60 \\
\text { V, 2, s. } 188 ; \\
\text { AAL, Rep } 60 \\
\text { A 205, s. } \\
304 v ; \text { AAL, } \\
\text { Rep 60 IX 1, } \\
\text { s. 44, 45, 277- } \\
\text { 278; AAL, } \\
\text { Rep 60 IX 3, } \\
\text { s. 536v }\end{array}$ \\
\hline \multirow{3}{*}{108.} & \multirow{3}{*}{ Ryki } & św. Anny & 1638 & - & 1808,1889 & $\begin{array}{l}\text { AAL, Rep } 60 \\
\text { A 197, s. 344; } \\
\text { AAL, Rep } 60 \\
\text { IX 3, s. 538v }\end{array}$ \\
\hline & & Różańcowe & 1637 & - & 1808 & $\begin{array}{l}\text { AAL, Rep } 60 \\
\text { A } 197, \text { s. } 344\end{array}$ \\
\hline & & Szkaplerzne & 1637 & - & 1808,1889 & $\begin{array}{l}\text { AAL, Rep } 60 \\
\text { A 197, s. 344; } \\
\text { AAL, Rep } 60 \\
\text { IX 3, s. 538v }\end{array}$ \\
\hline 109. & $\begin{array}{c}\text { Rzeczyca } \\
\text { Ziemiańska }\end{array}$ & Różańcowe & - & - & 1889 & $\begin{array}{l}\text { AAL, Rep } 60 \\
\text { IX } 3, \text { s. } 537 \mathrm{v}\end{array}$ \\
\hline \multirow{2}{*}{110.} & \multirow{2}{*}{ Rzeplin } & Św. Trójcy & - & - & 1830 & $\begin{array}{c}\text { AAL, Rep } 60 \\
\text { A 208, s. } \\
385 \mathrm{v}\end{array}$ \\
\hline & & Różańcowe & - & - & 1830 & $\begin{array}{c}\text { AAL, Rep } 60 \\
\text { A 208, s. } \\
385 \mathrm{v}\end{array}$ \\
\hline \multirow{2}{*}{111.} & \multirow{2}{*}{ Samogoszcz } & Różańcowe & 1725 & - & 1808,1889 & $\begin{array}{c}\text { AAL, Rep } 60 \\
\text { A 197, s. } \\
\text { 191v; AAL, } \\
\text { Rep } 60 \text { IX 3, } \\
\text { s. } 538 \mathrm{v}\end{array}$ \\
\hline & & Szkaplerzne & 1739 & - & 1808,1889 & $\begin{array}{c}\text { AAL, Rep } 60 \\
\text { A 197, s. } \\
\text { 191v; AAL, } \\
\text { Rep } 60 \text { IX 3, } \\
\text { s. } 538 \mathrm{v}\end{array}$ \\
\hline
\end{tabular}




\begin{tabular}{|c|c|c|c|c|c|c|}
\hline 112. & Sawin & Różańcowe & $25 \times 1750$ & - & $\begin{array}{c}1830,1833, \\
1889\end{array}$ & $\begin{array}{c}\text { AAL, Rep } 60 \\
\text { A 206, s. } \\
\text { 261v; AAL, } \\
\text { Rep } 60 \text { IX 1, } \\
\text { s. } 18,273- \\
\text { 274; AAL, } \\
\text { Rep } 60 \text { IX } 3 \text {, } \\
\text { s. } 537\end{array}$ \\
\hline 113. & $\begin{array}{l}\text { Siennica } \\
\text { Różana }\end{array}$ & Różańcowe & 26 IX 1756 & 6 II 1757 & $\begin{array}{l}1803,1830, \\
1833,1889\end{array}$ & $\begin{array}{c}\text { AAL, Rep } 60 \\
\text { A } 191, \text { s. } 80 \text { v; } \\
\text { AAL, Rep } 60 \\
\text { A } 206, \text { s. } 6 ; \\
\text { AAL, Rep } 60 \\
\text { IX } 1, \text { s. } 16, \\
27,273-274 \text {, } \\
\text { 312; AAL, } \\
\text { Rep } 60 \text { IX } 3 \text {, } \\
\text { s. } 537 \mathrm{v}\end{array}$ \\
\hline 114. & Sitaniec & Różańcowe & 1852 & - & 1889 & $\begin{array}{c}\text { AAL, Rep } 60 \\
\text { IX 3, s. } 538\end{array}$ \\
\hline 115. & Skibniew & Św. Trójcy & $1817^{59}$ & - & 1808,1889 & $\begin{array}{c}\text { AAL, Rep } 60 \\
\text { A 198, s. 138; } \\
\text { AAL, Rep } 60 \\
\text { IX 3, s. } 540\end{array}$ \\
\hline 116. & Skierbieszów & Różańcowe & 1755 & - & 1817,1889 & $\begin{array}{c}\text { AAL, Rep } 60 \\
\text { A 203, s. 451; } \\
\text { AAL, Rep } 60 \\
\text { IX 3, s. } 538\end{array}$ \\
\hline 117. & Sokołów & Różańcowe & $1826^{60}$ & - & 1808,1889 & $\begin{array}{c}\text { AAL, Rep } 60 \\
\text { A 198, s. } 93 ; \\
\text { AAL, Rep } 60 \\
\text { IX 3, s. } 540\end{array}$ \\
\hline 118. & $\begin{array}{c}\text { Stary } \\
\text { Zamość }\end{array}$ & Różańcowe & 1757 & - & 1889 & $\begin{array}{c}\text { AAL, Rep } 60 \\
\text { IX 3, s. } 538\end{array}$ \\
\hline 119. & Syrniki & $\begin{array}{l}\text { św. Marii } \\
\text { Magdaleny }\end{array}$ & - & - & 1800,1889 & $\begin{array}{c}\text { AAL, Rep } 60 \\
\text { A 184, s. 267; } \\
\text { AAL, Rep } 60 \\
\text { IX 3, s. } 538\end{array}$ \\
\hline 120. & $\begin{array}{l}\text { Szczebrze- } \\
\text { szyn } \\
\text { (kościół szpi- } \\
\text { talny) }\end{array}$ & Różańcowe & $28 \times 1742$ & - & 1833,1834 & $\begin{array}{c}\text { AAL, Rep } 60 \\
\text { IX 1, s. } 253 \text {, } \\
255,269-270\end{array}$ \\
\hline
\end{tabular}

${ }^{59} \mathrm{~W}$ spisie z 1889 r. jako data wprowadzenia tego bractwa podany jest rok 1817. Jako że bractwo to zostało odnotowane we wcześniejszych źródłach należy przypuszczać, że mogło to być ponowne jego wprowadzenie (AAL, Rep 60 IX 3, s. 540).

${ }^{60} \mathrm{~W}$ spisie z $1889 \mathrm{r}$. jako data wprowadzenia tego bractwa podany jest rok 1826. Jako że bractwo to zostało odnotowane we wcześniejszych źródłach należy przypuszczać, że mogło to być ponowne jego wprowadzenie (AAL, Rep 60 IX 3, s. 540). 


\begin{tabular}{|c|c|c|c|c|c|c|}
\hline 121. & Świerze & Różańcowe & 13 XI 1748 & 12 VIII 1758 & $\begin{array}{c}1804,1830 \\
1833\end{array}$ & $\begin{array}{c}\text { AAL, Rep } 60 \\
\text { A } 192, \text { s. } 88 ; \\
\text { AAL, Rep } 60 \\
\text { A 206, s. } 303 ; \\
\text { AAL, Rep } 60 \\
\text { IX 1, s. } 13, \\
\text { 26, 275-276, } \\
312\end{array}$ \\
\hline 122. & Targowiska & Szkaplerzne & 29 IV $1614^{61}$ & - & $\begin{array}{c}1801,1827, \\
1833,1889\end{array}$ & $\begin{array}{c}\text { AAL, Rep } 60 \\
\text { A } 186, \text { s. } 48 ; \\
\text { AAL, Rep } 60 \\
\text { V, 2, s. } 124 \mathrm{v} ; \\
\text { AAL, Rep } 60 \\
\text { IX 1, s. } 128 \\
271-272 ; \\
\text { AAL, Rep } 60 \\
\text { IX 3, s. } 537 \mathrm{v}\end{array}$ \\
\hline 123. & Tarnogóra & Różańcowe & 1639 & 1640 & 1803,1827 & $\begin{array}{c}\text { AAL, Rep } 60 \\
\text { A } 191, \mathrm{~s} . \\
182 \mathrm{v} ; \text { AAL, } \\
\text { Rep } 60 \mathrm{~V}, 2, \\
\text { s. } 90 \mathrm{v}\end{array}$ \\
\hline 124. & Tarnogród & Różańcowe & 1635 & - & 1830,1889 & $\begin{array}{c}\text { AAL, Rep } 60 \\
\text { A 208, s. 6; } \\
\text { AAL, Rep } 60 \\
\text { IX 3, s. } 537\end{array}$ \\
\hline 125. & Tomaszów & $\begin{array}{l}\text { Różańcowe } \\
\text { Szkaplerzne }\end{array}$ & $\begin{array}{c}13 \mathrm{~V} 1817^{62} \\
1827\end{array}$ & - & $\begin{array}{c}1833,1889 \\
1889\end{array}$ & $\begin{array}{c}\text { AAL, Rep } 60 \\
\text { IX 1, s. } 256, \\
269-270 ; \\
\text { AAL, Rep } 60 \\
\text { IX 3, s. } 538 \\
\\
\text { AAL, Rep } 60 \\
\text { IX 3, s. } 538\end{array}$ \\
\hline 126. & Trzeszczany & Św. Trójcy & $1818-1820$ & - & 1830,1833 & $\begin{array}{c}\text { AAL, Rep } 60 \\
\text { A 207, s. } \\
\text { 186v; AAL, } \\
\text { Rep } 60 \text { IX 1, } \\
\text { s. } 64-65,263- \\
264,313-314\end{array}$ \\
\hline 127. & Tuchowicz & Różańcowe & $1639^{63}$ & - & 1807,1889 & $\begin{array}{c}\text { AAL, Rep } 60 \\
\text { A 196a, s. 25; } \\
\text { AAL, Rep } 60 \\
\text { IX 3, s. } 539\end{array}$ \\
\hline
\end{tabular}

${ }^{61} \mathrm{~W}$ spisie z 1889 r. jako data wprowadzenia tego bractwa podany jest rok 1664 (AAL, Rep 60 IX 3, s. 537v).

${ }^{62}$ Bractwo istniało dużo wcześniej, jednak wszystkie dokumenty zabrali Austriacy i postanowiono je oficjalnie przywrócić (AAL, Rep 60 IX 1, s. 256).

${ }^{63} \mathrm{~W}$ spisie z 1889 r. jako data wprowadzenia tego bractwa podany jest rok 1677 (AAL, Rep 60 IX 3, s. 539). 


\begin{tabular}{|c|c|c|c|c|c|c|}
\hline 128. & Turobin & $\begin{array}{l}\text { św. Anny } \\
\text { Różańcowe }\end{array}$ & $\begin{array}{r}1598 \\
\\
1637\end{array}$ & 28 VIII 1646 & $\begin{array}{c}1803,1827, \\
1833,1889 \\
\\
1827,1833, \\
1889\end{array}$ & $\begin{array}{c}\text { AAL, Rep } 60 \\
\text { A 191, s. 303; } \\
\text { AAL, Rep } 60 \\
\text { V, 2, s. } 119 \mathrm{v} ; \\
\text { AAL, Rep } 60 \\
\text { IX 1, s. 118, } \\
\text { 271-272; } \\
\text { AAL, Rep } 60 \\
\text { IX 3, s. 537v } \\
\\
\text { AAL, Rep } 60 \\
\text { V, 2, s. } 119 \mathrm{v} ; \\
\text { AAL, Rep } 60 \\
\text { IX 1, s. 119, } \\
271-272 ; \\
\text { AAL, Rep } 60 \\
\text { IX 3, s. } 537 \mathrm{v}\end{array}$ \\
\hline 129. & Tyszowce & Różańcowe & - & - & 1830 & $\begin{array}{l}\text { AAL, Rep } 60 \\
\text { A } 208 \text {, s. } 296 \\
\end{array}$ \\
\hline 130. & Uchanie & $\begin{array}{l}\text { Św. Trójcy } \\
\text { Różańcowe }\end{array}$ & $\begin{array}{c}- \\
1484\end{array}$ & $\begin{array}{l}- \\
-\end{array}$ & $\begin{array}{l}1833 \\
1889\end{array}$ & $\begin{array}{c}\text { AAL, Rep } 60 \\
\text { IX 1, s. } 64- \\
65,263-264 \\
\text { AAL, Rep } 60 \\
\text { IX 3, s. } 537\end{array}$ \\
\hline 131. & Ulan & $\begin{array}{l}\text { Miłosierdzia } \\
\text { Różańcowe }\end{array}$ & $\begin{array}{c}\text { koniec } \\
\text { XVIIIw. } \\
\text { - }\end{array}$ & $\begin{array}{l}- \\
-\end{array}$ & $\begin{array}{l}1807 \\
1889\end{array}$ & $\begin{array}{c}\text { AAL, Rep } 60 \\
\text { A 196a, s. } \\
174 \\
\text { AAL, Rep } 60 \\
\text { IX 3, s. } 539 \\
\end{array}$ \\
\hline 132. & Urzędów & $\begin{array}{l}\text { Różańcowe } \\
\text { Literackie } \\
\text { św. Anny }\end{array}$ & $\begin{array}{c}5 \times 1721 \\
1489 \\
1593\end{array}$ & - & $\begin{array}{c}1801,1833, \\
1889 \\
1801^{64} \\
1801^{65}\end{array}$ & $\begin{array}{c}\text { AAL, Rep } 60 \\
\text { A } 186, \text { s. } 293 ; \\
\text { AAL, Rep } 60 \\
\text { IX 1, s. } 212, \\
265-266 ; \\
\text { AAL, Rep } 60 \\
\text { IX 3, s. } 537 \mathrm{v} \\
\text { AAL, Rep } 60 \\
\text { A } 186, \text { s. } 293 \\
\text { AAL, Rep } 60 \\
\text { A } 186, \text { s. } 293\end{array}$ \\
\hline
\end{tabular}

${ }^{64}$ Bractwo wówczas praktycznie już nie funkcjonowało (zob. M. Surdacki, Bractwo Literackie w Urzędowie 1489-1800, ABMK, 79 (2003) s. 429).

${ }^{65}$ Bractwo uległo całkowitemu upadkowi już pod koniec XVIII wieku (zob. M. Surdacki, Bractwo św. Anny w Urzędowie (1593-1787), „Roczniki Nauk Społecznych”, 30 (2002) z. 2, s. 127). 


\begin{tabular}{|c|c|c|c|c|c|c|}
\hline 133. & Wąwolnica & $\begin{array}{l}\text { Różańcowe } \\
\text { Literackie }\end{array}$ & 6 IX 1700 & 17 IV 1723 & $\begin{array}{l}1800,1803, \\
1833,1889 \\
1800,1803\end{array}$ & $\begin{array}{c}\text { AAL, Rep } 60 \\
\text { A } 183, \text { s. } 147 ; \\
\text { AAL, Rep } 60 \\
\text { A 190, s. 146; } \\
\text { AAL, Rep 60 } \\
\text { IX 1, s. 105, } \\
\text { 113-114, 261- } \\
\text { 262; AAL, } \\
\text { Rep } 60 \text { IX 3, } \\
\text { s. 536v } \\
\text { AAL, Rep } 60 \\
\text { A 183, s. } 147 ; \\
\text { AAL, Rep } 60 \\
\text { A 190, s. } 146\end{array}$ \\
\hline 134. & Wielącza & Różańcowe & $10 \times 1717^{66}$ & - & $\begin{array}{l}1817,1832 \\
1833,1889\end{array}$ & $\begin{array}{c}\text { AAL, Rep } 60 \\
\text { A 203, s. } 100 ; \\
\text { AAL, Rep } 60 \\
\text { A 207, s. } 88 \text { v; } \\
\text { AAL, Rep } 60 \\
\text { IX 1, s. 250- } \\
251,269-270 ; \\
\text { AAL, Rep } 60 \\
\text { IX 3, s. } 538\end{array}$ \\
\hline 135. & Wilkołaz & Św. Trójcy & 1753 & 1754 & 1801,1889 & $\begin{array}{l}\text { AAL, Rep } 60 \\
\text { A 185, s. 506; } \\
\text { AAL, Rep } 60 \\
\text { IX 3, s. 537v }\end{array}$ \\
\hline 136. & Wilków & Różańcowe & 1730 & - & $\begin{array}{c}1801,1830 \\
1889\end{array}$ & $\begin{array}{c}\text { AAL, Rep } 60 \\
\text { A } 185, \text { s. } 259 ; \\
\text { AAL, Rep } 60 \\
\text { A } 189, \text { s. } 4 ; \\
\text { AAL, Rep } 60 \\
\text { A 205, s. } 226 ; \\
\text { AAL, Rep } 60 \\
\text { IX 3, s. 536v }\end{array}$ \\
\hline 137. & Wojcieszków & Różańcowe & $1636^{67}$ & - & 1807 & $\begin{array}{l}\text { AAL, Rep } 60 \\
\text { A 196a, s. 5; } \\
\text { AAL, Rep } 60 \\
\text { IX 3, s. 539v }\end{array}$ \\
\hline 138. & Zaklików & Różańcowe & - & - & 1801,1814 & $\begin{array}{l}\text { AAL, Rep } 60 \\
\text { A } 186, \text { s. } 690 ; \\
\text { AAL, Rep } 60 \\
\text { A } 199, \text { s. } 26\end{array}$ \\
\hline
\end{tabular}

${ }^{66} \mathrm{~W}$ spisie z 1889 r. jako data wprowadzenia tego bractwa podany jest rok 1703 (AAL, Rep 60 IX 3, s. 538).

${ }^{67}$ J. Flaga podaje, że w roku 1636 bractwo uzyskało aprobatę, natomiast wprowadzone zostało w 1628 roku (Flaga, Bractwa religijne w archidiakonacie lubelskim, s. 326). 


\begin{tabular}{|c|c|c|c|c|c|c|}
\hline 139. & Zakrzówek & Różańcowe & 10 X 1790 & - & & $\begin{array}{c}\text { AAL, Rep 60 } \\
\text { A 185, s. 563; } \\
\text { AAL, Rep 60 } \\
\text { IX 1, s. 218, } \\
\text { 265-266, 318; } \\
\text { AAL, Rep 60 } \\
\text { IX 3, s. 537v }\end{array}$ \\
\hline 140. & Zamość & Różańcowe & 1678 & - & 1889 & $\begin{array}{c}\text { AAL, Rep 60 } \\
\text { IX 3, s. 538 }\end{array}$ \\
\hline 141. & Zemborzyce & Szkaplerzne & 1743 & - & 1800 & $\begin{array}{c}\text { AAL, Rep 60 } \\
\text { A 182, s. 234 }\end{array}$ \\
\hline 142. & Zembrów & Różańcowe & 1722 & - & 1808,1889 & $\begin{array}{c}\text { AAL, Rep 60 } \\
\text { A 198, s. 178; } \\
\text { AAL, Rep 60 } \\
\text { IX 3, s. 540 }\end{array}$ \\
\hline 143. & Żalin & Różańcowe & 1758 & 1759 & 1889 & $\begin{array}{c}\text { AAL, Rep 60 } \\
\text { IX 3, s. 537 }\end{array}$ \\
\hline
\end{tabular}

Słowa kluczowe: bractwa religijne, diecezja lubelska, gubernia lubelska, XIX wiek, zabory

\section{RELIGIOUS BROTHERHOODS IN THE DIOCESE OF LUBLIN IN THE NINETEENTH CENTURY. NUMERICAL DATA}

\section{Summary}

The brotherhood movement was born in the Church in the fourth century. Brotherhoods usually operated in churches and monasteries, and their aim was to strengthen the piety of the faithful through the implementation of the objectives of charitable and social activities, as well as activities connected with worship. In Poland, religious brotherhoods appeared in the thirteenth century and developed over the centuries. They flourished in the seventeenth and eighteenth century and were introduced into the majority of parishes. At the end of the fourteenth century they appeared in the region of Lublin. In the period before the partitions there were 174 brotherhoods in that region. With the collapse of the Polish State religious brotherhoods also experienced a serious crisis.

The Diocese of Lublin was founded in 1805 . Under the new organizational 
structures brotherhoods continued to operate and pursue their goals. Despite a series of reprisals from the partitioners, which wanted to tightly control and even restrict the activity of brotherhoods, they effectively coped with those difficulties opposing the secularization of society. On the basis of the records of canonical visitation of the nineteenth century and the two registrations of brotherhoods in that period, it was possible to establish that in the nineteenth century in the Diocese of Lublin there were 199 brotherhoods. The vast majority of brotherhoods were Marian ones - 124, of which 91 Rosary ones, 24 scapular ones and 9 others. Among other fraternities quite numerously represented were the ones dedicated to the Holy Trinity (24), St. Anna (15), Mercy (12). The number of such fraternities as Corpus Christi (3), St. Tekla (3), St. John of Nepomuk (3) Literary (2), St. Anthony (2) and Heart of Jesus (2) was small. There was also one brotherhood of Guardian Angels, one of the Holy Name of Jesus, Lovers of Crucified Jesus, Merciful Jesus (dying), St. Cross, St. Mary Magdalene, St. Barbara, St. Yvonne and St. Francis of Assisi's belt. Some of them disappeared at the beginning of the nineteenth century, some operated continuously for a long time and others came into existence in the period under discussion.

It is hoped that the issue concerning the functioning of religious brotherhoods in the nineteenth century will soon be more detailed studied, as in the case of the fraternities operating in the period before the Partitions of Poland. It is essential to better understand not only the functioning of the brotherhoods in an entirely new political situation of the Polish Church but also their impact on moral and religious renewal, and perhaps on the increase in the patriotic sentiments of wider social groups.

Keywords: religious brotherhoods, the Diocese of Lublin, the Province of Lublin, the nineteenth century, annexed territories 